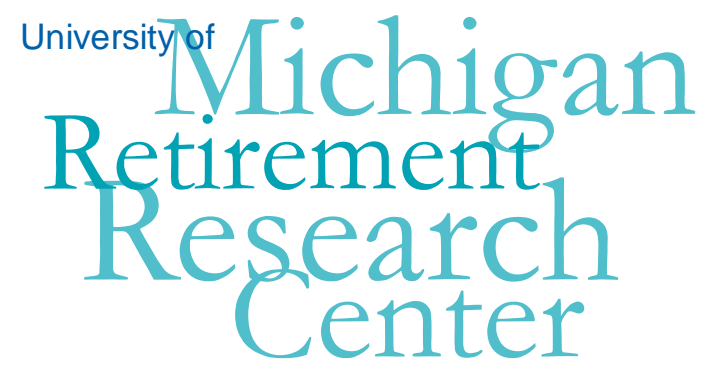

Working Paper

WP 2010-223

\title{
Financial Knowledge and Financial Literacy at the Household Level
}

Alan L. Gustman, Thomas L. Steinmeier and Nahid Tabatabai

\begin{tabular}{|l|l|}
\hline $\mathrm{M}$ & $\mathrm{R}$ \\
\hline $\mathrm{R}$ & $\mathrm{C}$ \\
\hline
\end{tabular}$\quad$ Project \#: UM10-12 


\title{
Financial Knowledge and Financial Literacy at the Household Level
}

\author{
Alan L. Gustman \\ Dartmouth College and NBER \\ Thomas L. Steinmeier \\ Texas Tech University \\ Nahid Tabatabai \\ Dartmouth College \\ September 2010
Michigan Retirement Research Center
University of Michigan
P.O. Box 1248
Ann Arbor, MI 48104
http://www.mrrc.isr.umich.edu/
(734) 615-0422

\section{Acknowledgements}

This work was supported by a grant from the Social Security Administration through the Michigan Retirement Research Center (Grant \# 10-M-98362-5-01). The findings and conclusions expressed are solely those of the author and do not represent the views of the Social Security Administration, any agency of the Federal government, or the Michigan Retirement Research Center.

\section{Regents of the University of Michigan}

Julia Donovan Darrow, Ann Arbor; Laurence B. Deitch, Bingham Farms; Denise Ilitch, Bingham Farms; Olivia P. Maynard, Goodrich; Andrea Fischer Newman, Ann Arbor; Andrew C. Richner, Grosse Pointe Park; S. Martin Taylor, Gross Pointe Farms; Katherine E. White, Ann Arbor; Mary Sue Coleman, ex officio 


\title{
Financial Knowledge and Financial Literacy at the Household Level
}

\begin{abstract}
This paper uses data from the Health and Retirement Study to explore the mechanism that underlies the robust relation found in the literature between cognitive ability, and in particular numeracy, and wealth, income constant. We have a number of findings. First, the more valuable the pension, the more knowledgeable are covered workers about their pensions. We suggest that causality is more likely to run from pension wealth to pension knowledge, rather than the other way around. Second, most measures of cognitive ability, including numeracy, are not significant determinants of pension and Social Security knowledge. Third, standardizing for incomes and other factors, a pension of higher value does not substitute for other forms of wealth. Rather, counting pensions in total wealth, those with more valuable pensions save more for retirement, other things the same. Fourth, there is no evidence that wealth held outside of pensions is influenced by knowledge of pensions.

In sum, numeracy does not influence wealth in whole or in part by affecting financial knowledge of one's pension plan, where financial knowledge of the pension then influences other decisions about retirement saving.

These findings raise questions about the mechanism that underlies the relation between cognition, especially numeracy, and wealth. From a policy perspective, they suggest that the numeracy-wealth relation should not be taken as evidence that increasing financial literacy will increase the wealth of households as they enter into retirement.
\end{abstract}

\section{Authors’ Acknowledgements}

This research was supported by a grant from the U.S. Social Security Administration (SSA) through the Michigan Retirement Research Center under grant number UM10-12. Measures of knowledge of pensions and Social Security are drawn from our recent book Pensions in the Health and Retirement Study, based on work principally supported by NIA grant R01 AG024337, "Behavioral Analysis in Structural Retirement Models". The findings and conclusions expressed are solely those of the authors and do not represent the views of SSA, NIA, or the MRRC. We are grateful to James Smith and Jonathan Zinman for suggestions and comments. 


\section{Introduction}

Pensions and Social Security together account for half the wealth of those approaching retirement age. Thus one would expect knowledge of pensions and Social Security to play a central role in shaping the financial decisions made by those in their early to mid-fifties. In addition, recent studies confirm a link between numeracy and household wealth (Lusardi and Mitchell, 2006; Banks and Oldfield, 2007). Indeed, measures of numeracy, based on simple questions testing the ability to calculate fractions, percentages and compounding, seem to dominate more elaborate measures of cognition in explaining the wealth of those approaching retirement age (McArdle, Smith and Willis, 2009) $)^{2}$. Thus one would suspect there is a link between numeracy and knowledge of pensions and Social Security, so that, holding the influence of cognition on earnings constant, each plays a role in shaping the accumulation of retirement wealth.

To learn more about these potential relationships, we use the Health and Retirement Study to create a number of measures of knowledge of pensions and Social Security. We then demonstrate that knowledge of pensions is higher where the value of the pension is higher. Next we consider the relation of cognition to pension knowledge, with special emphasis on the role played by numeracy. Following that, we relate wealth held outside of pensions and Social Security to measures of

\footnotetext{
${ }^{2}$ McArdle, Smith and Willis describe a set of measures of the various dimensions of cognitive ability being developed as part of an ongoing survey that is complementary to the Health and Retirement Study. Their research focuses on measures of cognition taken directly from the psychology literature, including measures of the stock of accumulated knowledge (crystallized intelligence) and the dimensions of cognitive ability associated with processing decisions (fluid intelligence).

The measures of cognition from their new survey are not yet available in a sample that also includes detailed measures of pension and Social Security wealth from respondents and employers, allowing development of an array of measures of pension and Social Security knowledge. Both sets of measures will eventually be available for the HRS once the 2010 wave is returned from the field and the respondent information from that wave is supplemented by administrative data. The 2010 wave includes the new set of cognition questions, detailed questions about pensions and Social Security, and eventually will have matched employer produced pension plan descriptions and Social Security earnings histories. Right now, however, detailed measures of cognition are only available for a small share of the HRS population in an experimental module.

Therefore, we proceed by using the less elaborate measures of numeracy and other dimensions of cognition that are currently available in the HRS. These same measures are used by McArdle, Smith and Willis (2009) in a portion of their paper. (Also see Ofstedal, Fisher and Herzog, 2005). Supporting this decision, their work suggests that in explaining wealth, the more elaborate measures of cognition are dominated by simple measures of numeracy, which are available to us.
} 
cognition, including numeracy, to measures of knowledge of pensions and Social Security, and to wealth accumulated in the form of pensions. We consider the relationship to total wealth as well.

In some respects, our analysis conforms to our expectations. In other respects, it generates surprises, and more disturbing, inconsistencies that are difficult to square with simple stories of the demand for and effects of knowledge on economic decision making. To be more specific:

We are able to generate a number of measures of pension and Social Security knowledge indicating knowledge of plan type, age of eligibility for retirement benefits and benefit amounts. Some of the measures of pension knowledge are directly related to pension wealth; the more valuable the pension, the more knowledgeable the covered worker. Apparently, those whose pensions are valuable enough to make it worthwhile to understand them are more likely to be knowledgeable about their pensions. Moreover, most pension wealth held by those in their early and mid-fifties is in defined benefit plans. Given the wage premium paid on these jobs and the history of changes in these plans, causality is more likely to run from pension wealth to pension knowledge, rather than the other way around. So far, so good.

A first puzzle is that most measures of cognitive ability, including numeracy, are not significant determinants of pension and Social Security knowledge.

A second puzzle is related to findings by previous researchers and confirmed in our earlier work with HRS data (Cagan, 1965; Katona, 1965; Gustman and Steinmeier, 1999). The amount of wealth a household accumulates outside of pensions and Social Security does not decline as the value of the household's pension wealth increases, income constant. That is, standardizing for individual differences such as time preference, pensions do not seem to be a substitute for other forms of wealth. As a result, counting pensions in total wealth, those with pensions save more for retirement. The hypothesis set forth by earlier researchers is that pensions lead to greater understanding of the mechanics of saving and a greater appreciation of the need for retirement 
saving. This suggests that wealth held outside of pensions should be related to knowledge of pensions. But we can find no evidence in support of that relationship.

A third and related puzzle is that knowledge of pensions has no effect on the relation of cognition to wealth. We duplicate results from McArdle, Smith and Willis (2009) indicating that there is a relation between cognition, and in particular numeracy, and wealth held outside of pensions and Social Security. However, once we find that knowledge of pensions and Social Security is not strongly related to the wealth accumulated by the retirement age population, and knowledge of pensions and Social Security is not related to cognition, it follows, and we find, that inclusion of pension knowledge in wealth equations does not affect the estimated relation between numeracy and wealth. So we must conclude that numeracy does not influence wealth in whole or in part by affecting financial knowledge of one's pension plan, where financial knowledge of the pension then influences other decisions about retirement saving.

These findings not only raise questions about the role of knowledge of pensions and Social Security in shaping retirement saving, but they also raise questions about the linkage between numeracy and wealth. Not whether there is one -- the evidence supports the existence of such a link. The question is how it works. We had thought that one avenue through which numeracy influences wealth is through an effect on understanding of financial instruments. But no financial instrument is more crucial to retirement saving than pensions and Social Security. So we are left with the question, what is the channel through which numeracy affects wealth accumulated by the age of retirement?

To set the stage for the empirical analysis, Section II provides further discussion of the role that knowledge of pensions and Social Security may play in influencing the relation of cognition to wealth. In Section III we discuss the construction of the measures of pension knowledge, cognition and wealth used in the analysis. Section IV analyzes the relation of measures of knowledge of 
pensions and Social Security to measures of cognition. Section V analyzes first individually, and then jointly, the relation of measures of knowledge of pensions and Social Security, and cognition, to retirement wealth. Section VI concludes.

\section{An Intermediary Role for Knowledge of Pensions and Social Security?}

A. Cognition and Knowledge of Pensions and Social Security

If higher cognitive ability leads to a greater appreciation of the need for retirement saving, or to more effective saving for retirement, one might also expect higher cognitive ability to be accompanied by greater knowledge of the instruments used in saving for retirement. Pensions and Social Security account for half of the wealth of U.S. households nearing retirement age.

One possibility is that those with higher cognitive ability have greater knowledge of pensions and of Social Security, which may contribute to their accumulating greater wealth. Even if there is no direct causality running from cognition through knowledge of pensions and Social Security to wealth, one would expect at least an indirect association where, holding measures of income constant, those with highest levels of cognition accumulate greater wealth because they recognize the need for retirement saving, and at the same time accrue greater knowledge of financial instruments.

An indirect linkage might also arise if numeracy leads to increased planning activities, which in turn affect wealth (Lusardi and Mitchell, 2007). Once again, through this route one might also expect to find numeracy linked to knowledge of the two most important sources of financial wealth at retirement age, pensions and Social Security.

B. Knowledge of Pensions and the Level of Non-Pension, Non-Social Security Wealth.

In Gustman and Steinmeier (1999) we found support for earlier findings by Cagan (1965) and Katona (1965) regarding the relation of pensions to saving. Contrary to the view that pensions are a simple, tax favored substitute for other forms of saving, data from the 1992 HRS suggested 
that pension coverage and pension values bear very little relation to saving outside of pensions. That is, those with pensions save roughly the same amount outside of their plans as do those without pensions who have comparable lifetime incomes. Where there is some substitution between pensions and other forms of wealth, it is only for those with higher levels of income and education. For the rest, there is little apparent substitution of pensions for other wealth, even holding constant a number of factors that might reflect differences in taste for saving. Partly, this is because an important fraction of the population does not save for retirement outside of pensions and Social Security. But of greater interest, even for those who do save in other forms, in many cases there is little substitution. So those with pensions typically have higher total wealth than those without pensions, income and other factors the same.

It is important to standardize for incomes when investigating the pension-wealth relation. Jobs offering a pension also offer higher wages (Gustman and Steinmeier, 1993.) But even when we did standardize for lifetime incomes, the positive link between pensions and wealth continued.

Another possible reason for a pension-wealth relation has been suggested by Cagan (1965) and Katona (1965). Their idea is that those with pensions may have been made more aware of the need for retirement saving, and so saved more. It certainly is in the interest of employers to insure that covered workers appreciate the contributions they are making to the workers' pensions. But if the linkage between pensions and other wealth stemmed from the greater understanding of the need for retirement saving by those with pensions, one would also expect to find a relationship between knowledge of pension plans and saving in other forms. This will lead to one of the major hypotheses we will be testing. If Cagan and Katona were right, we should find that greater knowledge of pensions is associated with higher wealth accumulated outside of the pension, income constant. 
Still another possibility is that those with higher values of time preference may find pensions an imperfect substitute for wealth in hand. But in our earlier work, we could find no evidence that time preference was driving the relation between pensions and other forms of wealth.

\section{Pension Knowledge and Total Wealth}

What might account for the lack of a relationship between knowledge of pensions and Social Security on the one hand, and retirement wealth on the other? There is evidence that many of those with pensions are disengaged from the management of their plans. Most pensions held by those in their fifties are defined benefit plans. Even among those with substantial balances in defined contribution plans, many never rebalance their portfolios. Others rebalance infrequently, even during the course of a recession. Many are not aware of the details of their plans. Many do not focus until they are very near their retirement ages. Thus the lack of a relation between pension knowledge and total wealth, earnings constant, may simply reflect the disengagement of those with pensions from the management of their plans. But why then would they be so aware of the need to accumulate wealth held in other forms than pensions and Social Security? People handle other forms of wealth more frequently. Thus cognition, and in particular numeracy, may affect the value of other forms of wealth as long as people are paying more attention to, and are engaged in transactions involving these other forms of wealth. But would this attention to other wealth be the same for those with and without pensions?

In trying to understand the relationship between pension knowledge and total wealth, there is another puzzle. In exploring measures of pension knowledge similar to those reported here, Gustman and Steinmeier (2001) found that respondents to the Health and Retirement Study who overestimated the values of their pensions and Social Security in a base year, 1992, did not eventually change their saving or retirement behavior in future years, by saving more or delaying their retirement relative to their initial plans. Nor did those who had understated their plan values 
change their behavior, taking advantage of the unexpected excess in assets to save less in subsequent years, or to retire earlier than previously planned.

D. The Relation of Cognition to Wealth

In attempting to understand the relation of cognitive ability to wealth, it is important to realize that there need not be a statistical relationship. Additional cognitive ability might raise earnings, but holding earnings constant, greater cognitive ability may or may not be associated with the accumulation of additional wealth. Higher cognitive ability may reduce mistakes people make in choosing how much to save for retirement, but those mistakes might have resulted in either over saving or under saving. Moreover, higher cognitive ability might reduce uncertainty, but greater uncertainty about needs in retirement might increase precautionary saving, or it may lead to a lower valuation of the effect of current saving on utility gained by additional consumption in retirement and thereby reduce saving.

Or basic numeracy might lead directly to the accumulation of additional wealth for retirement. Most obviously, more able individuals may gain higher returns on their retirement assets, allocating their assets to tax favored instruments, to investments with a higher payoff and lower fees, or they may make fewer mistakes adjusting their portfolios over time. More able individuals may also realize the need to save for retirement, while the issue may either escape the attention of those who have difficulties making financial calculations, or who may simply be overwhelmed by the task. Some with lower cognitive ability may be unable to understand the need for substantial retirement saving so they eventually will be able to support their current consumption in retirement, let alone to determine the amount of wealth required to meet their consumption needs in retirement.

If numeracy reduces financial errors, this would create a direct link between numeracy and wealth that would not necessarily involve greater specific knowledge of pensions and Social 
Security. One such linkage has been investigated by Zinman and Stango (2009). They find evidence relating misunderstanding of how compound interest works to financial wealth. Their argument is that the tendency to linearize the exponential growth of interest leads to greater borrowing and lower levels of wealth. In a similar vein, Gerardi, Goette and Meier (2010) find that lower numeracy is associated with greater chance of delinquency and default in the subprime housing market.

\section{Sample and Construction of Variables}

The sample used in our analysis is based on respondents to the Health and Retirement Study from couple households. The sample is restricted to the early boomer cohort, those from households with at least one member age 51 to 56 in 2004. We restrict the sample to the early boomer cohort because it is the first HRS cohort for which we have measures of numeracy at the time they entered the survey. We focus on those 51 to 56 because most measures of pension knowledge in the HRS are derived from questions asking about pensions on the respondent's current job. ${ }^{3}$ Typically, those jobs offering pensions to respondents over the age of fifty are the same jobs they held at prime working age. Thus we do not want to select an older population where those remaining on their long term job are not representative of workers who were ever covered by a pension.

\section{A. Measures of Pension Variables}

Using HRS data, it is possible to construct a number of measures of pension and Social Security knowledge. A basic measure distinguishes between respondents who answer “don’t know” (dk) to questions about pension and Social Security characteristics or values and those who do answer the relevant questions. Another measure compares respondent answers with values

\footnotetext{
${ }^{3}$ In the HRS, those who have already retired are not asked about their expected benefits. Those who are older than the early retirement age are not asked about their early retirement benefits. Those who are older than the normal retirement age are not asked about their normal retirement benefits.
} 
calculated by evaluating employer plan descriptions using the relevant respondent's work histories. Questions about pensions include plan type, age of eligibility for early and normal retirement benefits, benefit amounts to be paid to holders of defined benefit plans at early or normal retirement ages, account balances in defined contribution plans, and related questions. Knowledge of Social Security benefits is measured by the frequency of don't know responses to questions about benefits at early and normal retirement ages. When analyzing the frequency of don't know responses, we use two different measures. One measure is a simple don't know response to the question. The second indicator classifies the respondent as not knowing the answer only if the respondent responds "don't know" to the initial question, and when presented with a series of bracketed values for the variable in question continues to respond "don’t know".

The subsamples of the early boomer population used for analysis varies with the measure of pension or Social Security knowledge being analyzed. For example, if we are investigating knowledge of the account balance in a defined contribution plan, the sample is limited to the subset of the population with a defined contribution pension. Similarly, if we are investigating knowledge of annual benefits to be paid at expected retirement age for those with a defined benefit plan, the sample is limited to those with a defined benefit plan. Empirical work reported in the appendices demonstrates that the main findings are not affected by the differences in population base created by the use of different measures of pension and Social Security knowledge.

Descriptive data for some of the measures of knowledge of pensions and Social Security used in our analysis are reported in Appendix Table 2, Part B. Some measures will be more useful than others. For example, only 3 percent of those with a pension indicate they do not know their plan type. This will limit the usefulness of the dk plan type measure in our later analysis. On the other hand, when we use indicators of whether the respondent and firm agree, there is much more variation in the knowledge measures. For example, the measure of agreement as to plan type is 
based on a broad measure of agreement. There we say the respondent and firm reported the same plan type either when there is exact agreement, or when one reported one plan type, say DB, while the other reported coverage by both plan types. When the broad measure of agreement is used, the level of agreement is very high, at 88 percent. The frequency of agreement is much lower when we use a narrower definition of plan type. For example, to say the respondent and firm both agree the plan type is DB only, as in row 6 of Appendix Table 2, Part B, or DC only, as in row 7, they both must respond the plan type is DB only or DC only. If either responds both, there is no match. The frequency of agreement is much lower when narrow agreement is required, with 10 percent of respondents agreeing the plan is DB only, and 16 percent agreeing the plan is DC only.

The measure of whether respondents know the value of their Social Security benefits, either at the early or normal age of eligibility, exhibits considerable variability. In Part C of Appendix Table 2, 37 percent of respondents say they do not know what their Social Security benefits would be at the Social Security early age of benefit eligibility, and 32 percent say they don't know their benefits at the normal Social Security entitlement age.

\section{B. Measures of Cognition}

Our analysis uses three indicators of cognition from the Health and Retirement Study (HRS), TICS questions, word recall and numeracy. These are available in the core of the HRS for the early boomer cohort, and as noted in the previous section have been shown in earlier studies to be significantly correlated with wealth.

Two “TICS” (Telephone Interview of Intact Cognitive Status) questions are used here. They rate a person's ability to serially subtract 7 from 100, and to count backward (from 20 to 1$)^{4}$.

\footnotetext{
${ }^{4}$ McArdle, Smith and Willis (2009) investigate the relation of cognition to wealth for all HRS respondents over the age of fifty. They include additional TICS measures beside the two included in our analysis. The additional measures help to discriminate levels of cognition among those over 65. One such measure evaluates a second try at backward counting for those who failed the first try. Others of the additional TICS questions ask about knowledge of the date of the interview, names of the President and Vice President, the name of the device for cutting paper, and the name for a prickly plant that grows in the desert. We do not include these additional measures in this paper because we
} 
Backward counting equals 2 if the respondent could correctly count at the first try. Otherwise it equals zero. The Series 7 value is the sum of correct answers to any of the questions in the series. The range for TICS is from 0 to 7.

Word recall refers to an individual's recall of a list of words, using the average of the sum of correct answers to the immediate and delayed word recalls. It ranges between 0 and 10 .

The measure of numeracy is the sum of the number of correct answers to three questions, asking for calculations involving compound interest, fractions and probability. One question asks for the calculation of how many people out of 1000 would be sick if there were a 10 percent chance of contracting a disease. Second, if there were five winners of a lottery offering a \$2 million prize, what will each receive? Third, with \$200 in a saving account earning 10 percent interest per year, what will be in the account at the end of two years? Numeracy ranges from 0 to 3.

Descriptive statistics for the cognition variables for various subsamples of the Early Boomer cohort used in our analysis are reported in Appendix Table 1.

C. Measures of Wealth

When relating knowledge to wealth, two measures of wealth are used alternatively as dependent variables. The first is total wealth excluding pensions and Social Security wealth. This measure includes stocks and other financial instruments, the value of the home, real estate, business wealth, ownership of autos, and other sources of wealth. The second measure is total wealth including the wealth equivalent of pensions and Social Security. Given the findings that we discussed from earlier studies, where pensions seemed to increase saving in other forms, when analyzing the relation between wealth and financial knowledge we include pension wealth on the right hand side of the relevant regressions. Our findings regarding the relation of cognition and/or

focus on the population ages 51 to 56, where these measures are not very helpful in determining differences in cognition. 
pension knowledge to wealth are not, however, sensitive to whether pension wealth is included as a covariate.

\section{Relation of Knowledge of Pensions and Social Security to Numeracy}

Table 1 reports the results of a series of probit equations relating various measures of respondent knowledge of their pensions and Social Security to the level of current pension wealth (or DB or DC wealth where appropriate), and to measures of cognition, including the score from two elements of the TICS variables (backward counting and serial sevens), word recall and numeracy. ${ }^{5}$ A number of covariates listed below the table are also included. The cells in the table are dprobits, reporting the effect of a one unit change in the independent variable on the probability of observing the knowledge measure.

The table is divided into three sections according to whether the dependent variable pertains to plan type, retirement age, or to the value of the pension.

We first consider evidence supporting a partial, but important, underlying economic explanation for knowledge of pensions. Knowledge of pensions is greater if the plan is more valuable. Pension wealth measures are significant at conventional levels in explaining the following measures of pension knowledge. Those with higher pension wealth are more likely to agree with their employer as to plan type, are less likely to say they do not know the early retirement age for their defined contribution plan, are more likely to agree with their firm about the age they will be eligible for early retirement benefits, are less likely to say they do not know the value of their

\footnotetext{
${ }^{5}$ Gustman and Steinmeier (2005a) related these knowledge measures to the HRS indicator of word recall, but found no significant results. Other studies that include measures of cognitive ability, using very simple measures of knowledge of pensions, find that numeracy is related to pension knowledge (e.g., see Banks and Oldfield, 2007). Their measure of pension knowledge is an indicator of whether or not the respondent says they know the benefit accrual rate, or the level of pension benefits. That is, they focus on dk responses. The relation of numeracy to these outcomes remains significant even when there are controls for other dimensions of cognitive ability and education.
} 
defined benefit pensions at normal retirement age, and are more likely to agree with their firm on the amount of benefits their DB plan is expected to pay.

We do not believe there is strong reverse causality, with greater knowledge of pensions leading to higher pension wealth. To be sure, greater knowledge may lead to higher contribution rates to DC plans, and more effective investment strategies. But it is harder to make the case that a relationship between knowledge of defined benefit plans and pension wealth is due to reverse causality. Yet for the population approaching retirement age examined in this paper, DB plans represent two thirds of pension wealth. The value of a defined benefit plan depends only on the earnings and experience of the covered worker, not on any additional activity that may be disproportionately undertaken by better informed individuals. Nor do we believe that selection into pension jobs is an important issue. Jobs with pensions carry much higher wages, which are likely to have driven the choice of employment when the worker was younger. ${ }^{6}$

The results describing how respondents' knowledge of their pensions or Social Security varies with the respondent's level of cognition are not nearly so straight-forward to understand. Indeed, taken together, these findings contribute to a major puzzle.

Consider the coefficient on numeracy in row 1, column 4 of Table 1 . A one unit increase in numeracy, which means the individual answered an additional one of the three numeracy questions, increases the probability of a respondent reporting he or she does not know the plan type by 2.6 percent. Of course, here the sign is in the "wrong" direction.

To be sure, taken by itself this result is not so surprising. Ninety-seven percent of respondents claim they know their plan type. So there is little variation in the dependent variable to

\footnotetext{
${ }^{6}$ At the time they joined their firms, those approaching retirement age in 2004 faced plan provisions that were quite different from those found in later years. Moreover, pension jobs, especially those offering defined benefit plans, were typically in unionized firms and large firms that paid premium wages, making the jobs attractive irrespective of the pension offer. For further discussion, see Gustman, Steinmeier and Tabatabai (2010), chapter 2.
} 
be explained, and the perverse sign can be treated as an anomaly. It makes no sense that increased numeracy would increase the number saying they don’t know their plan type.

Yet a similar relation is found between numeracy and other measures of knowledge of plan type. For example, as seen in row 2, column 4, the probability that the respondent and firm agree on the type of pension plan is lower by 3.9 percent for those who have greater numeracy. That is, greater numeracy leads to a reduction in agreement between respondent and firm reports of plan type.

Nor do the measures of cognition help in explaining other measures of plan type, whether don't know responses, or indicators that the respondent's answer is the same as that from the matched employer plan description. Although some coefficients are significant, there are no systematic relations between measures of cognition and plan type that are consistent and plausible. Nor do the coefficients change when pension wealth is no longer included as a covariate. Thus it is not that one set of results or another is ignoring some indirect path from cognition to knowledge of plan type.

One might argue that knowledge of plan type is not an appropriate indicator of knowledge of one’s pension. That is why we have tried such a wide range of other indicators of pension knowledge. Yet we find no plausibly consistent effect of any of the indicators of cognition on knowledge of pensions and Social Security.

Thus Section B of Table 1 presents analogous results on the relation of cognition to knowledge of retirement age. Once again, there are no consistent and plausible relations between measures of cognition and an indicator of knowledge of a respondent's pension.

Section C of Table 1 takes us to indicators of the relation of numeracy to knowledge of benefit values. When covariates are included, there is no effect of numeracy on knowledge of plan values. Especially telling here, numeracy is not related to knowledge of DC plan values. 
We also include in the last two rows of the table indicators of the respondents' knowledge of their Social Security benefits. Counter intuitively, the result in the last row of column 4, which approaches significance, suggests that greater numeracy increases the likelihood of saying one doesn't know Social Security benefits at normal retirement age.

So to this point, it would appear that, although earlier studies have shown that cognition, and numeracy in particular, significantly affect wealth held outside of defined benefit pensions and Social Security, they have no effect on knowledge of pensions. This result may create some doubt about the efficacy of the many cognition variables we have examined. Given an expectation that these measures of cognition improve wealth by increasing basic knowledge of financial instruments, one would expect each of these measures, TICS (serial 7 and backward counting), word recall and numeracy, to bear a systematic and consistent relation to measures of knowledge of pensions and Social Security. But they do not.

So we are left wondering why the measures of knowledge of pensions are influenced so strongly by pension values, but are virtually unaffected by measures of cognition. This mystery will deepen as we examine the joint relation between knowledge of pensions and Social Security, cognition, and the value of wealth. 
Table 1: Marginal Effects of Cognition Measures on Pension Knowledge: Ages 51-56 in 2004

\begin{tabular}{|c|c|c|c|c|c|}
\hline Dependent Variables & $\begin{array}{l}\text { Pension/ } \\
\text { DB/DC } \\
\text { Wealth }\end{array}$ & $\begin{array}{c}\text { TICS } \\
\text { (absolute z) }\end{array}$ & $\begin{array}{l}\text { Word Recall } \\
\text { (absolute z) }\end{array}$ & $\begin{array}{l}\text { Numeracy } \\
\text { (absolute z) }\end{array}$ & $\begin{array}{l}\text { \# of Obs. } \\
\text { Pseudo R2 }\end{array}$ \\
\hline \multicolumn{6}{|l|}{$\begin{array}{c}\text { A. Indicators of Plan } \\
\text { Type }\end{array}$} \\
\hline DK plan type & $\begin{array}{l}0.032 \\
(1.44)\end{array}$ & $\begin{array}{l}-0.002 \\
(0.34)\end{array}$ & $\begin{array}{l}-0.002 \\
(0.37)\end{array}$ & $\begin{array}{l}0.026 \\
(2.31)\end{array}$ & $\begin{array}{c}651 \\
0.2455\end{array}$ \\
\hline $\begin{array}{l}\text { R \& firm agree on all } \\
\text { plan types } \\
\text { (wider restriction) }\end{array}$ & $\begin{array}{l}0.164 \\
(2.92)\end{array}$ & $\begin{array}{l}0.005 \\
(0.55)\end{array}$ & $\begin{array}{l}0.024 \\
(2.82)\end{array}$ & $\begin{array}{l}-0.039 \\
(2.07)\end{array}$ & $\begin{array}{c}626 \\
0.1621\end{array}$ \\
\hline $\begin{array}{l}\mathrm{R} \& \text { firm agree plan } \\
\text { is } \mathrm{DB}\end{array}$ & $\begin{array}{l}-0.025 \\
(0.29)\end{array}$ & $\begin{array}{l}-0.015 \\
(1.07)\end{array}$ & $\begin{array}{l}-0.004 \\
(0.27)\end{array}$ & $\begin{array}{l}0.010 \\
(0.33)\end{array}$ & $\begin{array}{c}431 \\
0.1365\end{array}$ \\
\hline $\begin{array}{l}\mathrm{R} \& \text { firm agree plan } \\
\text { is DC }\end{array}$ & $\begin{array}{l}-0.057 \\
(0.48)\end{array}$ & $\begin{array}{l}-0.013 \\
(0.57)\end{array}$ & $\begin{array}{l}0.013 \\
(0.80)\end{array}$ & $\begin{array}{l}-0.005 \\
(0.16)\end{array}$ & $\begin{array}{c}404 \\
0.3418\end{array}$ \\
\hline $\begin{array}{l}\mathrm{R} \text { reports DB \& firm } \\
\text { reports DC plan }\end{array}$ & $\begin{array}{l}-0.022 \\
(1.36)\end{array}$ & $\begin{array}{l}0.004 \\
(1.08)\end{array}$ & $\begin{array}{l}-0.006 \\
(2.15)\end{array}$ & $\begin{array}{l}0.006 \\
(0.94)\end{array}$ & $\begin{array}{c}527 \\
0.2644\end{array}$ \\
\hline $\begin{array}{l}\mathrm{R} \text { reports DC \& firm } \\
\text { reports DB plan }\end{array}$ & $\begin{array}{l}-0.133 \\
(2.96)\end{array}$ & $\begin{array}{l}-0.003 \\
(0.55)\end{array}$ & $\begin{array}{l}-0.002 \\
(0.40)\end{array}$ & $\begin{array}{l}0.013 \\
(1.15)\end{array}$ & $\begin{array}{c}505 \\
0.2144\end{array}$ \\
\hline \multicolumn{6}{|l|}{$\begin{array}{l}\text { B. Indicators of } \\
\text { Retirement Age }\end{array}$} \\
\hline DK- ER age for DB & $\begin{array}{l}-0.062 \\
(1.16)\end{array}$ & $\begin{array}{l}-0.004 \\
(0.57)\end{array}$ & $\begin{array}{l}0.003 \\
(0.46)\end{array}$ & $\begin{array}{l}-0.010 \\
(0.65)\end{array}$ & $\begin{array}{c}725 \\
0.1758\end{array}$ \\
\hline DK- NR age for DB & $\begin{array}{l}-0.003 \\
(0.10)\end{array}$ & $\begin{array}{l}0.003 \\
(0.65)\end{array}$ & $\begin{array}{l}0.007 \\
(1.54)\end{array}$ & $\begin{array}{l}0.005 \\
(0.52)\end{array}$ & $\begin{array}{c}725 \\
0.2320\end{array}$ \\
\hline DK- ER age for DC & $\begin{array}{l}-0.197 \\
(2.20)\end{array}$ & $\begin{array}{l}-0.008 \\
(0.91)\end{array}$ & $\begin{array}{l}0.001 \\
(0.13)\end{array}$ & $\begin{array}{l}-0.011 \\
(0.63)\end{array}$ & $\begin{array}{c}1013 \\
0.1262\end{array}$ \\
\hline $\begin{array}{l}\text { R and Firm agree on } \\
\text { ER age }\end{array}$ & $\begin{array}{l}0.448 \\
(2.99)\end{array}$ & $\begin{array}{l}0.015 \\
(0.63)\end{array}$ & $\begin{array}{l}-0.010 \\
(0.43)\end{array}$ & $\begin{array}{l}0.071 \\
(1.42)\end{array}$ & $\begin{array}{c}361 \\
0.1046\end{array}$ \\
\hline $\begin{array}{l}\text { R and Firm agree on } \\
\text { NR age }\end{array}$ & $\begin{array}{l}0.177 \\
(1.22)\end{array}$ & $\begin{array}{l}0.023 \\
(0.97)\end{array}$ & $\begin{array}{l}-0.025 \\
(1.09)\end{array}$ & $\begin{array}{l}-0.032 \\
(0.66)\end{array}$ & $\begin{array}{c}350 \\
0.0886\end{array}$ \\
\hline \multicolumn{6}{|l|}{$\begin{array}{l}\text { C. Indicators of Plan } \\
\text { Value }\end{array}$} \\
\hline $\begin{array}{l}\text { DK- NR benefits for } \\
\text { DB }\end{array}$ & $\begin{array}{l}-0.284 \\
(1.82)\end{array}$ & $\begin{array}{l}0.016 \\
(0.74)\end{array}$ & $\begin{array}{l}0.032 \\
(1.57)\end{array}$ & $\begin{array}{l}-0.018 \\
(0.41)\end{array}$ & $\begin{array}{c}729 \\
0.5286\end{array}$ \\
\hline $\begin{array}{l}\text { DK- XP benefits for } \\
\text { DB* }\end{array}$ & $\begin{array}{l}-0.330 \\
(1.44)\end{array}$ & $\begin{array}{l}0.036 \\
(1.14)\end{array}$ & $\begin{array}{l}0.014 \\
(0.42)\end{array}$ & $\begin{array}{l}-0.033 \\
(0.43)\end{array}$ & $\begin{array}{c}725 \\
0.8618\end{array}$ \\
\hline $\begin{array}{l}\mathrm{R} \text { and Firm agree on } \\
\text { expected } \mathrm{DB} \\
\text { benefits }\end{array}$ & $\begin{array}{l}0.201 \\
(4.31)\end{array}$ & $\begin{array}{l}-0.001 \\
(0.10)\end{array}$ & $\begin{array}{l}-0.010 \\
(1.03)\end{array}$ & $\begin{array}{l}-0.017 \\
(0.76)\end{array}$ & $\begin{array}{c}350 \\
0.3854\end{array}$ \\
\hline DK- DC balances & $\begin{array}{l}0.075 \\
(0.77)\end{array}$ & $\begin{array}{l}-0.003 \\
(0.12)\end{array}$ & $\begin{array}{l}-0.023 \\
(1.15)\end{array}$ & $\begin{array}{l}-0.008 \\
(0.20)\end{array}$ & $\begin{array}{c}1076 \\
0.8087\end{array}$ \\
\hline DK after brackets in & 0.017 & -0.000 & -0.001 & 0.007 & 1062 \\
\hline
\end{tabular}




\begin{tabular}{|l|c|c|c|c|c||}
\hline Dependent Variables & $\begin{array}{c}\text { Pension/ } \\
\text { DB/DC } \\
\text { Wealth }\end{array}$ & $\begin{array}{c}\text { TICS } \\
\text { (absolute z) }\end{array}$ & $\begin{array}{c}\text { Word Recall } \\
\text { (absolute z) }\end{array}$ & $\begin{array}{c}\text { Numeracy } \\
\text { (absolute z) }\end{array}$ & $\begin{array}{c}\text { \# of Obs. } \\
\text { Pseudo R2 }\end{array}$ \\
\hline \hline DC balances & $(1.41)$ & $(0.16)$ & $0.24)$ & $(1.25)$ & 0.3965 \\
\hline DK- SS benefits at & 0.068 & -0.002 & 0.008 & 0.019 & 2392 \\
ER age & $(1.09)$ & $(0.29)$ & $(0.94)$ & $(1.07)$ & 0.0958 \\
\hline DK- SS benefits at & -0.009 & -0.002 & 0.004 & 0.032 & 2415 \\
NR age & $(0.15)$ & $(0.26)$ & $(0.49)$ & $(1.80)$ & 0.0893 \\
\hline
\end{tabular}

Other covariates include indicators of respondent's union and public employment status, measures of TICS, Recall and Numeracy for the respondent's spouse, a series of dummy variables for respondent's education, dummy variables indicating whether the respondent is female, nonwhite, Hispanic, age and age squared for respondent and spouse, spouse's school years, whether respondent is financially knowledgeable R, dummy variables indicating Social Security Wealth on an if claim now basis $(<50,000 ; 50,000$ to100,000 omitted; 100,000 to 150,000; 150,000 to 200,000; >200,000) [these measures are due to Kandice Kapinos of the Health and Retirement Study], dummy variables for missing values including those who were proxies, whether the respondent answered $\mathrm{dk}$ to questions about cognition variables, and a dummy if pension wealth is imputed. Current pension, DB, and DC wealth are in millions of dollars. DB wealth includes a calculation of the present value of the respondent's expected DB benefits for his/her most important DB plan. DC wealth includes the sum of all DC accounts from R's current job.

* Nine cases who reported they have a DB plan from their current job, but that they were receiving benefits currently, are excluded.

z-statistics are reported in parentheses. 


\section{Relation of Household Wealth to Each Spouse's Knowledge of Their Pension and Social Security, to Cognitive Ability, and to Other Key Covariates.}

So far we have not been able to find a relation of cognition to knowledge of pensions and Social Security. We have, however, found a relation between knowledge of pensions and Social Security and the level of pension wealth. There also are the findings of a strong relationship between cognition and wealth from McArdle, Smith and Willis (2009). We put these findings together by estimating the relation of total wealth to pension and Social Security knowledge, including pension wealth as a covariate. Next, using a sample comparable to the one we use to analyze pension knowledge, we reestimate the results from McArdle, Smith and Willis (2009), linking wealth to cognition. Third, we include all three elements in the same regression. This will allow us to answer three questions: Does knowledge of pensions and Social Security bear any systematic relation to non-pension, non-Social Security wealth? What is the role of pension wealth in influencing the relation of pension knowledge to other forms of wealth? Does knowledge of pensions and Social Security affect the measured relation between cognition and wealth?

To begin, estimates in Table 2 relate the wealth of a respondent's household to that person's knowledge of their pensions and Social Security. Observations are respondent based, with one observation for each individual member of couple households with at least one of them aged 51 to 56 in 2004 and having a pension. Three different measures of wealth alternate as dependent variables. Results for total household wealth (in thousands of dollars) are reported in columns 1 and 2. Findings for the ratio of household wealth to household income are reported in columns 3 and 4. Regressions with total household wealth excluding pensions and Social Security as the dependent variable are reported in columns 5 and 6. Measures of knowledge of the respondent's pension and Social Security are the same as those discussed earlier. 
The results in Table 2 provide little support for a view that greater knowledge of pensions is a sign of the kind of greater financial sophistication that would increase retirement wealth. Columns 1, 3 and 5 of the table report the coefficients of the measure of pension or Social Security knowledge in the regressions for wealth. Only four out of thirty of these measures of knowledge exhibit coefficients that are significant at or near conventional levels. The coefficient in row 1, column 1, suggests that if a person reports not knowing what type of plan their pension is, that person will have $\$ 127,300$ less wealth than persons who say they know their plan type. In row 3, column 1 , when a respondent and firm agree the plan is defined benefit, the total wealth is $\$ 93,510$ higher.

However, among the four statistically significant results, there are also two counter-intuitive findings. Specifically, in column 5, rows 4 and 5, if a person indicates not knowing the early or normal retirement ages for a DB plan, household wealth outside of the pension is higher by $\$ 67,620$ and $\$ 48,570$ respectively.

Columns 2, 4 and 6 report the coefficients estimated for the measures of pension wealth, where this variable is entered into the right hand side of the alternative wealth regressions. Looking down columns 2 and 4, allowing for considerable variation in the coefficient estimates, and the fact that some coefficients differ significantly from 1.0, each dollar of pension wealth is associated with roughly another dollar in total wealth. This suggests little substitution of pension wealth for other forms of wealth. Respondents do not save less outside of their pension because they have access to more pension wealth. The last column relates total wealth excluding pensions and Social Security to pension wealth. Here the coefficients are significantly greater than zero, and suggest that those with pensions save slightly more in other forms for each dollar of additional pension wealth. Again, there is no suggestion of substantial substitution between pensions and other forms of wealth. 
To reconcile the coefficients in columns 2 and 6, note that column 6 tells us how a $\$ 1$ increase in pension wealth is related to wealth outside of both the pension and Social Security. Column 2 indicates how a $\$ 1$ increase in pension wealth is related to the sum of pension wealth, Social Security wealth, and wealth held outside of pensions and Social Security. Thus taking the result in row 4, it is perfectly consistent to find on the one hand that an additional dollar of pension wealth raises wealth outside of pensions and Social Security by 11.6 cents, while increasing total wealth by 83.9 cents. The difference reflects the correlation between pensions and Social Security. One final note. Although it might seem that a very limited effect of pension knowledge on total wealth is the result of holding pension wealth constant, the findings are similar when pension wealth is not included in the equations reported in Table 2. 
Table 2: Marginal Effects of Pension and Social Security Knowledge on Household Wealth: Ages 51-56 in 2004. (Note: Measures of cognition are not included in these regressions.)

\begin{tabular}{|c|c|c|c|c|c|c|}
\hline \multirow{2}{*}{$\begin{array}{c} \\
\\
\text { Independent } \\
\text { Pension Knowledge } \\
\text { Variables }\end{array}$} & \multicolumn{2}{|c|}{$\begin{array}{l}\text { Dependent Variable: HH } \\
\text { Total Wealth } \\
\text { (thousands of dollars) }\end{array}$} & \multicolumn{2}{|c|}{$\begin{array}{l}\text { Dependent Variable: Ratio } \\
\text { of HH Total Wealth to HH } \\
\text { Income }\end{array}$} & \multicolumn{2}{|c|}{$\begin{array}{l}\text { Dependent Variable: HH } \\
\text { Total Wealth Excluding } \\
\text { Pension \& SS Wealth } \\
\text { (thousands of dollars) }\end{array}$} \\
\hline & $\begin{array}{c}\text { Coefficient } \\
\text { for } \\
\text { Pension/SS } \\
\text { Knowledge } \\
\text { Variable } \\
\end{array}$ & $\begin{array}{l}\text { Coefficient } \\
\text { for Pension } \\
\text { Wealth } \\
\text { Variable }\end{array}$ & $\begin{array}{l}\text { Coefficient } \\
\text { for } \\
\text { Pension/SS } \\
\text { Knowledge } \\
\text { Variable }\end{array}$ & $\begin{array}{l}\text { Coefficient } \\
\text { for (Pension } \\
\text { Wealth/HH } \\
\text { Income) } \\
\text { Variable }\end{array}$ & $\begin{array}{l}\text { Coefficient } \\
\text { for } \\
\text { Pension/SS } \\
\text { Knowledge } \\
\text { Variable }\end{array}$ & $\begin{array}{l}\text { Coefficient } \\
\text { for Pension } \\
\text { Wealth } \\
\text { Variable }\end{array}$ \\
\hline \multicolumn{7}{|l|}{$\begin{array}{l}\text { A. Indicators of } \\
\text { Plan Type }\end{array}$} \\
\hline DK plan type & $\begin{array}{c}-127.30 \\
(2.22)\end{array}$ & $\begin{array}{c}1.120 \\
(30.30)\end{array}$ & $\begin{array}{c}0.33 \\
(0.59)\end{array}$ & $\begin{array}{c}0.979 \\
(34.56)\end{array}$ & $\begin{array}{l}-24.88 \\
(0.74)\end{array}$ & $\begin{array}{c}0.226 \\
(10.36)\end{array}$ \\
\hline $\begin{array}{l}\text { R \& firm agree on } \\
\text { all plan types } \\
\text { (wider restriction) }\end{array}$ & $\begin{array}{l}21.7 \\
(0.49)\end{array}$ & $\begin{array}{l}1.100 \\
(20.65)\end{array}$ & $\begin{array}{l}-0.57 \\
(1.29)\end{array}$ & $\begin{array}{l}0.996 \\
(16.45)\end{array}$ & $\begin{array}{l}14.97 \\
(0.63)\end{array}$ & $\begin{array}{l}0.180 \\
(6.29)\end{array}$ \\
\hline $\begin{array}{l}\mathrm{R} \& \text { firm agree plan } \\
\text { is } \mathrm{DB}\end{array}$ & $\begin{array}{l}93.51 \\
(1.79)\end{array}$ & $\begin{array}{l}0.985 \\
(9.96)\end{array}$ & $\begin{array}{c}0.33 \\
(0.65)\end{array}$ & $\begin{array}{c}0.881 \\
(10.04)\end{array}$ & $\begin{array}{l}25.95 \\
(1.04)\end{array}$ & $\begin{array}{l}0.139 \\
(2.95)\end{array}$ \\
\hline \multicolumn{7}{|l|}{$\begin{array}{l}\text { B. Indicators of } \\
\text { Retirement Age }\end{array}$} \\
\hline DK- ER age for DB & $\begin{array}{l}73.66 \\
(1.45)\end{array}$ & $\begin{array}{c}0.839 \\
(11.03)\end{array}$ & $\begin{array}{c}0.06 \\
(0.13)\end{array}$ & $\begin{array}{c}0.747 \\
(15.95)\end{array}$ & $\begin{array}{l}67.62 \\
(2.53)\end{array}$ & $\begin{array}{l}0.116 \\
(2.91)\end{array}$ \\
\hline DK- NR age for DB & $\begin{array}{l}67.07 \\
(1.15) \\
\end{array}$ & $\begin{array}{c}0.835 \\
(11.02)\end{array}$ & $\begin{array}{c}0.42 \\
(0.76) \\
\end{array}$ & $\begin{array}{c}0.749 \\
(16.03)\end{array}$ & $\begin{array}{l}48.57 \\
(1.60) \\
\end{array}$ & $\begin{array}{l}0.105 \\
(2.66) \\
\end{array}$ \\
\hline \multicolumn{7}{|l|}{$\begin{array}{l}\text { C. Indicators of } \\
\text { Plan Value }\end{array}$} \\
\hline $\begin{array}{l}\text { DK- NR benefits } \\
\text { for DB }\end{array}$ & $\begin{array}{l}49.89 \\
(1.21)\end{array}$ & $\begin{array}{c}0.850 \\
(11.10)\end{array}$ & $\begin{array}{c}0.54 \\
(1.40)\end{array}$ & $\begin{array}{c}0.752 \\
(16.13)\end{array}$ & $\begin{array}{l}46.67 \\
(2.14)\end{array}$ & $\begin{array}{l}0.118 \\
(2.93)\end{array}$ \\
\hline $\begin{array}{l}\text { DK- XP benefits } \\
\text { for DB* }\end{array}$ & $\begin{array}{l}-2.72 \\
(0.05) \\
\end{array}$ & $\begin{array}{c}0.837 \\
(10.96) \\
\end{array}$ & $\begin{array}{l}-0.06 \\
(0.11) \\
\end{array}$ & $\begin{array}{c}0.748 \\
(15.99) \\
\end{array}$ & $\begin{array}{l}26.74 \\
(0.92) \\
\end{array}$ & $\begin{array}{l}0.103 \\
(2.60) \\
\end{array}$ \\
\hline $\begin{array}{l}\mathrm{R} \text { and Firm agree } \\
\text { on expected DB } \\
\text { benefits }\end{array}$ & $\begin{array}{l}73.86 \\
(1.17)\end{array}$ & $\begin{array}{l}0.912 \\
(7.79)\end{array}$ & $\begin{array}{l}-0.43 \\
(0.78)\end{array}$ & $\begin{array}{l}0.826 \\
(8.90)\end{array}$ & $\begin{array}{l}-15.99 \\
(0.51)\end{array}$ & $\begin{array}{l}0.170 \\
(2.95)\end{array}$ \\
\hline DK- DC balances & $\begin{array}{l}-55.13 \\
(1.31)\end{array}$ & $\begin{array}{l}1.411 \\
(26.13)\end{array}$ & $\begin{array}{c}0.13 \\
(0.32)\end{array}$ & $\begin{array}{c}1.24 \\
(37.51)\end{array}$ & $\begin{array}{l}-26.92 \\
(1.04)\end{array}$ & $\begin{array}{c}0.355 \\
(10.77)\end{array}$ \\
\hline $\begin{array}{l}\text { DK- SS benefits at } \\
\text { ER age }\end{array}$ & $\begin{array}{l}14.60 \\
(0.67) \\
\end{array}$ & $\begin{array}{c}1.092 \\
(25.02)\end{array}$ & $\begin{array}{c}0.11 \\
(0.52) \\
\end{array}$ & $\begin{array}{c}1.05 \\
(22.92)\end{array}$ & $\begin{array}{l}11.01 \\
(0.85)\end{array}$ & $\begin{array}{l}0.248 \\
(9.54)\end{array}$ \\
\hline
\end{tabular}

Estimated with robust regression. Covariates not listed in the table include an indicator if respondent is female, race, age and age squared for respondent and spouse, a series of dummy variables for respondent's education, spouse's school years, whether respondent is financially knowledgeable $\mathrm{R}$, if a union member or public employee, dummy variables indicating Social Security Wealth on an if claim now basis ( $<50,000 ; 50,000$ to100,000 omitted; 100,000 to 150,000; 150,000 to 200,000; >200,000), dummy variables for missing values; , and a dummy if pension wealth is imputed. 
Before presenting wealth equations that include measures of pension knowledge together with measures of cognition, Table 3 provides a second baseline for the wealth regressions by including only cognition measures and other covariates, but not measures of pension knowledge as explanatory variables. The table presents estimates of marginal effects of the three key measures of cognition on wealth, TICS, word recall and numeracy. In alternative specifications, wealth is measured by non-pension, non-Social Security wealth and total wealth. The format of the equations is the same as in McArdle, Smith and Willis (2009), except that pension wealth is also included as a covariate. The population underlying the regressions in Table 3 is different from the one used in their analysis, which includes the entire HRS population for 2006. As noted previously, to enable us eventually to include measures of knowledge of pensions and Social Security, which are available for 2004, our sample for all tables is confined to couple households with at least one member 51 to 56 in 2004. In addition, so the estimates of the equations used to analyze the relation of cognition to wealth will be comparable to the samples used to analyze the effects of knowledge of pension plan type, retirement age and plan values, the results in Table 3 are confined in one set of regressions to those who report they are covered by a pension, and in another to those HRS respondents for whom there is a matched employer provided pension plan description.

Otherwise, these wealth equations are specified as in McArdle, Smith and Willis (2009). Specifically, cognition measures are reported separately for the financially knowledgeable respondent and the spouse. Note, however, that the financially knowledgeable respondent may not be the member of the household who has a pension. What the wealth regressions show is how the cognition of each spouse is related to the household's wealth, not how the cognition of the spouse with a pension is related to household wealth. 
None of our major findings are affected by differences between the populations used in the two studies. As in McArdle, Smith and Willis (2009), numeracy of the financially knowledgeable respondent is the dominant determinant of wealth among the six cognition measures shown. ${ }^{7}$

From row 3, columns 1 and 2 of Table 3, a one unit increase in the numeracy score for a financially knowledgeable respondent is associated with an additional \$26,000 in wealth accumulated outside of the pension and Social Security. From columns 3 and 4, among the population with a pension, higher numeracy for the financial $\mathrm{R}$ also increases the total wealth of the household. But it does not have a significant effect on total wealth within the population of those who have a matched employer pension.

\footnotetext{
${ }^{7}$ Although not reported here, we built a bridge between the wealth equations in McArdle Smith and Willis (2009) and those in this paper. Given the number of differences in the underlying samples, this bridge involves changing the specification of the wealth equation one difference at a time. We are grateful to Jim Smith, who provided the information required to duplicate the initial results from McArdle, Smith and Willis (2009).
} 
Table 3: Marginal Effects of Measures of Cognition and Current Pension on Household Wealth: Ages 51-56 in 2004 (Wealth is measured in thousands of dollars.)

\begin{tabular}{|c|c|c|c|c|}
\hline \multirow[b]{2}{*}{ Independent Variables } & \multicolumn{2}{|c|}{$\begin{array}{l}\text { Wealth Excluding Pensions and Social } \\
\text { Security }\end{array}$} & \multicolumn{2}{|c|}{$\begin{array}{l}\text { Wealth Including Pensions and Social } \\
\text { Security }\end{array}$} \\
\hline & Rs with Pension & $\begin{array}{l}\text { Rs with matched } \\
\text { pension }\end{array}$ & Rs with Pension & $\begin{array}{l}\text { Rs with matched } \\
\text { pension }\end{array}$ \\
\hline & (1) & (2) & (3) & (4) \\
\hline \multicolumn{5}{|l|}{ Financial $\mathbf{R}$} \\
\hline TICS & $\begin{array}{l}-6.17 \\
(1.49)\end{array}$ & $\begin{array}{l}-4.90 \\
(0.80)\end{array}$ & $\begin{array}{l}-2.94 \\
(0.43)\end{array}$ & $\begin{array}{c}7.33 \\
(0.67)\end{array}$ \\
\hline Word Recall & $\begin{array}{l}-9.45 \\
(2.42)\end{array}$ & $\begin{array}{c}1.76 \\
(0.30)\end{array}$ & $\begin{array}{l}-6.80 \\
(1.05)\end{array}$ & $\begin{array}{l}-0.91 \\
(0.09)\end{array}$ \\
\hline Numeracy & $\begin{array}{l}26.54 \\
(3.23)\end{array}$ & $\begin{array}{l}26.28 \\
(2.08)\end{array}$ & $\begin{array}{l}31.69 \\
(2.32)\end{array}$ & $\begin{array}{l}12.13 \\
(0.54)\end{array}$ \\
\hline \multicolumn{5}{|l|}{ Non-Financial $\mathbf{R}$} \\
\hline TICS & $\begin{array}{l}-4.04 \\
(0.99)\end{array}$ & $\begin{array}{l}-3.65 \\
(0.58)\end{array}$ & $\begin{array}{l}3.07 \\
(0.45)\end{array}$ & $\begin{array}{l}-12.21 \\
(1.09)\end{array}$ \\
\hline Word Recall & $\begin{array}{l}11.45 \\
(2.86)\end{array}$ & $\begin{array}{c}9.88 \\
(1.66)\end{array}$ & $\begin{array}{l}17.67 \\
(2.66)\end{array}$ & $\begin{array}{l}31.78 \\
(3.02)\end{array}$ \\
\hline Numeracy & $\begin{array}{l}15.56 \\
(1.69)\end{array}$ & $\begin{array}{l}27.15 \\
(1.97)\end{array}$ & $\begin{array}{l}21.76 \\
(1.42)\end{array}$ & $\begin{array}{l}19.41 \\
(0.80)\end{array}$ \\
\hline \multicolumn{5}{|l|}{ Covered Worker } \\
\hline Current Pension Wealth & $\begin{array}{l}0.139 \\
(6.92)\end{array}$ & $\begin{array}{l}0.126 \\
(4.53)\end{array}$ & $\begin{array}{c}0.942 \\
(28.20)\end{array}$ & $\begin{array}{c}0.949 \\
(19.39)\end{array}$ \\
\hline
\end{tabular}

Estimated with robust regression. Covariates not listed in the table include indices for female, financial R, Hispanic, non-white, household total income and its square, respondent's and his/her spouse's age and their squares, respondent's and his/her spouse's education.

t-statistics are reported in parentheses. 
The next step is to enter measures of cognition and pension and Social Security knowledge in the same regressions for wealth. Table 4 relates wealth excluding pensions and Social Security to these measures. Table 5 relates total wealth, including pensions and Social Security, to cognition and measures of pension knowledge. Given the effect of pension value on pension knowledge, and the relation of pension value to nonpension, non-Social Security wealth, the level of pension wealth is included as a covariate in each equation. Other covariates are listed below the table.

The results are divided into three sections: coefficients for the cognition measures for the financially knowledgeable respondent; coefficients for the cognition measures for the spouse who is not the financially knowledgeable respondent; and under the title "Covered Worker", measures of pension knowledge exhibited by the worker who is covered by a pension. Once again, there are three different sets of measures of pension knowledge - those pertaining to plan type, those pertaining to retirement age, and those pertaining to plan value.

There are three clear conclusions from the results in both tables. First, as seen in rows 3 and 6 of each table, numeracy of the financially knowledgeable respondent, followed by numeracy of the nonfinancial respondent, are the major cognitive determinants of wealth. Second, from Table 4, row 7, pension wealth is associated with a higher level of non-pension, non-Social Security wealth. Third, in a few cases, greater pension knowledge is associated with higher wealth, with some variables bordering on significance. But for the most part, pension knowledge is not a major determinant of either wealth held outside of the pension plan, or of total wealth.

Given the weak relation between measures of knowledge of pensions to measures of cognition, it is not surprising that the coefficients on knowledge variables are not affected when measures of cognition are added to wealth regressions, and coefficients on measures of cognition are not affected when measures of pension and Social Security knowledge are added to wealth regressions. It is not just that the insignificant variables measuring the effects of pension knowledge 
on wealth, in say, Table 2, column 5, remain insignificant when measures of cognition are added to the regression. It is that the coefficients on the cognition variables remain unchanged when measures of pension knowledge are added to the regression. This can be seen by comparing Table 3, column 2 with Table 4, column 1.

Notice that within Tables 4 and 5, the coefficients on numeracy and on pension wealth bounce around among regressions. Further examination suggests it is not the differences in covariates among regressions that is responsible. Rather, it is differences in samples that are responsible. The samples are restricted by the definition of the pension knowledge variable. Column 1 includes those with a pension and matched employer pension plan description. The sample in columns 2 and 3 include those with a pension who report having a defined benefit plan. In column 4, respondents have a matched employer plan description and a defined benefit plan. Column 5 includes those with a defined contribution plan. The sample for column 6 requires that the respondent report expecting Social Security benefits.

To summarize, although the specifications relating pension knowledge to wealth outside of pensions and Social Security do not suggest a relation between measures of pension knowledge and other forms of wealth, they all suggest that numeracy bears a significant relation to wealth outside of pensions and Social Security. As a consequence, including measures of pension knowledge has little or no effect on the estimated relation between measures of numeracy and wealth. 
Table 4: Marginal Effects of Measures of Financial Knowledge and Cognition on Household Wealth Excluding Pensions and Social Security: Ages 51-56 in 2004 (Wealth is measured in thousands of dollars.)

\begin{tabular}{|c|c|c|c|c|c|c|}
\hline & (1) & (2) & (3) & (4) & (5) & (6) \\
\hline \multicolumn{7}{|l|}{ Financial R } \\
\hline TICS & $\begin{array}{c}-4.73 \\
(0.77)\end{array}$ & $\begin{array}{c}-8.18 \\
(1.40)\end{array}$ & $\begin{array}{c}-9.22 \\
(1.57)\end{array}$ & $\begin{array}{c}-9.36 \\
(1.13)\end{array}$ & $\begin{array}{l}-4.47 \\
(0.81) \\
\end{array}$ & $\begin{array}{l}-7.89 \\
(1.66) \\
\end{array}$ \\
\hline Word Recall & $\begin{array}{c}0.41 \\
(0.07) \\
\end{array}$ & $\begin{array}{c}-5.59 \\
(1.01) \\
\end{array}$ & $\begin{array}{c}-5.05 \\
(0.91) \\
\end{array}$ & $\begin{array}{r}10.26 \\
(1.23) \\
\end{array}$ & $\begin{array}{l}-11.93 \\
(2.34) \\
\end{array}$ & $\begin{array}{l}-9.79 \\
(2.21) \\
\end{array}$ \\
\hline Numeracy & $\begin{array}{l}26.37 \\
(2.11)\end{array}$ & $\begin{array}{l}29.91 \\
(2.54)\end{array}$ & $\begin{array}{l}31.64 \\
(2.68)\end{array}$ & $\begin{array}{l}19.55 \\
(1.09)\end{array}$ & $\begin{array}{l}33.50 \\
(3.21)\end{array}$ & $\begin{array}{l}30.94 \\
(3.34)\end{array}$ \\
\hline \multicolumn{7}{|l|}{ Non-Financial $\mathbf{R}$} \\
\hline TICS & $\begin{array}{c}-3.51 \\
(0.56) \\
\end{array}$ & $\begin{array}{c}-6.41 \\
(1.15) \\
\end{array}$ & $\begin{array}{c}-7.15 \\
(1.27) \\
\end{array}$ & $\begin{array}{c}-0.37 \\
(0.04) \\
\end{array}$ & $\begin{array}{c}-6.54 \\
(1.19) \\
\end{array}$ & $\begin{array}{l}-4.49 \\
(0.98) \\
\end{array}$ \\
\hline Word Recall & $\begin{array}{c}9.23 \\
(1.56) \\
\end{array}$ & $\begin{array}{l}14.16 \\
(2.55)\end{array}$ & $\begin{array}{l}14.78 \\
(2.65)\end{array}$ & $\begin{array}{c}9.37 \\
(1.12) \\
\end{array}$ & $\begin{array}{l}10.16 \\
(1.92) \\
\end{array}$ & $\begin{array}{l}11.06 \\
(2.53) \\
\end{array}$ \\
\hline Numeracy & $\begin{array}{l}29.07 \\
(2.11) \\
\end{array}$ & $\begin{array}{c}7.91 \\
(0.62) \\
\end{array}$ & $\begin{array}{c}8.68 \\
(0.68) \\
\end{array}$ & $\begin{array}{l}36.34 \\
(1.95)\end{array}$ & $\begin{array}{l}22.06 \\
(1.85) \\
\end{array}$ & $\begin{array}{l}16.69 \\
(1.65) \\
\end{array}$ \\
\hline \multicolumn{7}{|l|}{ Covered Worker } \\
\hline $\begin{array}{l}\text { Current pension/DB/DC } \\
\text { wealth }\end{array}$ & $\begin{array}{l}0.120 \\
(4.34)\end{array}$ & $\begin{array}{l}0.049 \\
(1.37)\end{array}$ & $\begin{array}{l}0.045 \\
(1.26)\end{array}$ & $\begin{array}{l}0.107 \\
(1.92)\end{array}$ & $\begin{array}{l}0.251 \\
(7.96)\end{array}$ & $\begin{array}{l}0.156 \\
(6.39)\end{array}$ \\
\hline DK-Plan Type & $\begin{array}{l}-20.88 \\
(0.40)\end{array}$ & - & - & - & - & - \\
\hline $\begin{array}{l}\text { R and Firm Agree on All } \\
\text { Plan Types (Wider } \\
\text { Restriction) }\end{array}$ & $\begin{array}{l}10.52 \\
(0.40)\end{array}$ & - & - & - & - & - \\
\hline $\begin{array}{l}\mathrm{R} \text { and Firm Agree Plan is } \\
\mathrm{DB}\end{array}$ & $\begin{array}{l}10.07 \\
(0.42) \\
\end{array}$ & - & - & - & - & - \\
\hline DK-ER Age for DB & - & $\begin{array}{l}36.80 \\
(1.52)\end{array}$ & - & - & - & - \\
\hline DK- expected DB benefit & - & - & $\begin{array}{l}62.66 \\
(1.46)\end{array}$ & - & - & - \\
\hline $\begin{array}{l}\text { R \& firm agree on } \\
\text { expected DB benefits }\end{array}$ & - & - & - & $\begin{array}{l}-28.80 \\
(0.95) \\
\end{array}$ & - & - \\
\hline DK-DC Balances & - & - & - & - & $\begin{array}{l}-64.44 \\
(1.79) \\
\end{array}$ & - \\
\hline DK-ER Age for DC Plan & - & - & - & - & $\begin{array}{l}-21.42 \\
(1.14) \\
\end{array}$ & - \\
\hline DK- SS Ben at ER age & - & - & - & - & - & $\begin{array}{c}7.64 \\
(0.50) \\
\end{array}$ \\
\hline DK- SS Ben at NR age & - & - & - & - & - & $\begin{array}{l}-3.39 \\
(0.21)\end{array}$ \\
\hline
\end{tabular}

Estimated with robust regression. The dependent variable is household wealth excluding Social Security and pension benefits. Covariates not listed in the table include indices for female, financial R, Hispanic, non-white, household total income and its square, respondent's and his/her spouse's age and their squares, and respondent's and his/her spouse's education.

t-statistics are reported in parentheses. 
Table 5: Marginal Effects of Measures of Financial Knowledge and Cognition on Total Household Wealth: Ages 51-56 in 2004 (Wealth is measured in thousands of dollars.)

\begin{tabular}{|c|c|c|c|c|c|c|}
\hline Financial R & (1) & (2) & (3) & (4) & (5) & (6) \\
\hline TICS & $\begin{array}{c}7.05 \\
(0.65) \\
\end{array}$ & $\begin{array}{c}-14.16 \\
(1.28) \\
\end{array}$ & $\begin{array}{c}-14.86 \\
(1.34) \\
\end{array}$ & $\begin{array}{c}-11.97 \\
(0.78) \\
\end{array}$ & $\begin{array}{c}4.14 \\
(0.47) \\
\end{array}$ & $\begin{array}{l}-2.70 \\
(0.35) \\
\end{array}$ \\
\hline Word Recall & $\begin{array}{c}-2.88 \\
(0.28)\end{array}$ & $\begin{array}{c}-10.31 \\
(0.98)\end{array}$ & $\begin{array}{c}-9.83 \\
(0.94) \\
\end{array}$ & $\begin{array}{c}-11.03 \\
(0.72) \\
\end{array}$ & $\begin{array}{l}-7.53 \\
(0.91) \\
\end{array}$ & $\begin{array}{l}-7.15 \\
(1.00) \\
\end{array}$ \\
\hline Numeracy & $\begin{array}{c}9.20 \\
(0.42) \\
\end{array}$ & $\begin{array}{l}55.78 \\
(2.50) \\
\end{array}$ & $\begin{array}{l}57.15 \\
(2.56) \\
\end{array}$ & $\begin{array}{l}27.84 \\
(0.85) \\
\end{array}$ & $\begin{array}{l}43.32 \\
(2.57) \\
\end{array}$ & $\begin{array}{l}40.30 \\
(2.68) \\
\end{array}$ \\
\hline \multicolumn{7}{|l|}{ Non-Financial $\mathbf{R}$} \\
\hline TICS & $\begin{array}{c}-8.98 \\
(0.81)\end{array}$ & $\begin{array}{c}4.04 \\
(0.38)\end{array}$ & $\begin{array}{c}3.57 \\
(0.34)\end{array}$ & $\begin{array}{c}4.51 \\
(0.29)\end{array}$ & $\begin{array}{c}5.03 \\
(0.57)\end{array}$ & $\begin{array}{c}2.75 \\
(0.37)\end{array}$ \\
\hline Word Recall & $\begin{array}{l}31.31 \\
(3.00) \\
\end{array}$ & $\begin{array}{l}29.37 \\
(2.79)\end{array}$ & $\begin{array}{l}29.42 \\
(2.80) \\
\end{array}$ & $\begin{array}{l}27.52 \\
(1.80) \\
\end{array}$ & $\begin{array}{l}16.78 \\
(1.97) \\
\end{array}$ & $\begin{array}{l}18.36 \\
(2.59) \\
\end{array}$ \\
\hline Numeracy & $\begin{array}{l}22.18 \\
(0.91) \\
\end{array}$ & $\begin{array}{c}0.64 \\
(0.03) \\
\end{array}$ & $\begin{array}{c}-0.16 \\
(0.01) \\
\end{array}$ & $\begin{array}{l}40.39 \\
(1.18) \\
\end{array}$ & $\begin{array}{l}42.52 \\
(2.21) \\
\end{array}$ & $\begin{array}{l}26.62 \\
(1.63) \\
\end{array}$ \\
\hline \multicolumn{7}{|l|}{ Covered Worker } \\
\hline $\begin{array}{l}\text { Current pension/DB/DC } \\
\text { wealth }\end{array}$ & $\begin{array}{c}0.942 \\
(19.29) \\
\end{array}$ & $\begin{array}{c}0.689 \\
(10.14) \\
\end{array}$ & $\begin{array}{c}0.691 \\
(10.18) \\
\end{array}$ & $\begin{array}{l}0.755 \\
(7.38) \\
\end{array}$ & $\begin{array}{c}1.262 \\
(24.79) \\
\end{array}$ & $\begin{array}{c}0.901 \\
(22.74) \\
\end{array}$ \\
\hline DK-Plan Type & $\begin{array}{l}-59.33 \\
(0.64) \\
\end{array}$ & - & - & - & - & - \\
\hline $\begin{array}{l}\text { R and Firm Agree on All } \\
\text { Plan Types (Wider } \\
\text { Restriction) }\end{array}$ & $\begin{array}{l}-8.53 \\
(0.18)\end{array}$ & - & - & - & - & - \\
\hline $\begin{array}{l}\mathrm{R} \text { and Firm Agree Plan is } \\
\mathrm{DB}\end{array}$ & $\begin{array}{l}68.80 \\
(1.62) \\
\end{array}$ & - & - & - & - & - \\
\hline DK-ER Age for DB & - & $\begin{array}{r}19.34 \\
(0.42) \\
\end{array}$ & - & - & - & - \\
\hline $\begin{array}{l}\text { DK- Expected DB } \\
\text { Benefit }\end{array}$ & - & - & $\begin{array}{l}58.43 \\
(0.72) \\
\end{array}$ & - & - & - \\
\hline $\begin{array}{l}\text { R \& Firm Agree on } \\
\text { Expected DB Benefits }\end{array}$ & - & - & - & $\begin{array}{c}5.90 \\
(0.11) \\
\end{array}$ & - & - \\
\hline DK-DC Balances & - & - & - & - & $\begin{array}{l}-67.13 \\
(1.15) \\
\end{array}$ & - \\
\hline DK-ER Age for DC Plan & - & - & - & - & $\begin{array}{l}-80.39 \\
(2.66)\end{array}$ & - \\
\hline DK- SS Ben at ER age & - & - & - & - & - & $\begin{array}{l}16.73 \\
(0.67) \\
\end{array}$ \\
\hline DK- SS Ben at NR age & - & - & - & - & - & $\begin{array}{l}-7.40 \\
(0.28) \\
\end{array}$ \\
\hline
\end{tabular}

Estimated with robust regression. The dependent variable is household wealth including Social Security and pension benefits. Covariates not listed in the table include indices for female, financial R, Hispanic, non-white, household total income and its square, respondent's and his/her spouse's age and their squares, and respondent's and his/her spouse's education.

t-statistics are reported in parentheses. 


\section{Conclusions and Policy Implications}

Our initial hope in undertaking this paper was to shed further light on the role of cognition, and in particular of numeracy, in shaping wealth accumulated for retirement. We thought that a part of the link between cognition and wealth reflected the fact that higher cognition leads to increased knowledge of retirement finances, which in turn leads to higher wealth. This idea was strengthened not only by findings in the literature on the relation of cognition, and especially numeracy to wealth, but also by earlier findings linking pension knowledge to pension wealth, and a failure to find a reduction in nonpension saving to correspond with higher pension wealth.

We have not succeeded in establishing these linkages. Although we confirm the finding in the literature that higher cognition, and in particular greater numeracy, is associated with the accumulation of additional retirement wealth, we also find the initial evidence that more numerate individuals better understand their pensions or Social Security to be very fragile. Nor do we find evidence linking cognition or numeracy to wealth accumulation in association with increased knowledge of pensions and Social Security. Moreover, we do not find that the substitution of pensions for other forms of wealth varies with knowledge of pensions.

Instead we find that many of the questions as to the avenues through which cognition and numeracy increase retirement wealth remain unanswered. As a result, we remain unsure of how best to use the apparently robust numeracy-wealth relation in designing policies that are aimed at increasing retirement saving.

To be sure, many people do not have an incentive to understand their pensions and Social Security, even when reaching their early or mid-fifties. For some their plans 
are not sufficiently valuable to pay much attention. For others, their retirement is assured due to a generous pension that does not require monitoring. Perhaps most importantly, for those currently approaching retirement age, the largest share of their pension wealth remains in defined benefit plans where typically there is little for an individual to do in order to increase retirement benefits.

But shouldn't greater numeracy that leads to greater wealth accumulation also have created greater financial acumen, which is then reflected indirectly as increased knowledge of pensions? When the finding that those with pensions are motivated to accumulate higher balances outside of their pensions and Social Security was uncovered in the literature, it was argued that those with pensions learn from their providers about the need for retirement saving and perhaps increased their understanding of how wealth accumulation works. Yet knowledge of pensions and Social Security does not affect saving behavior.

Why does numeracy play an important role in influencing saving, even holding income constant, while knowledge of pensions plays none?

When combined with findings from our earlier studies, many puzzles remain. In previous work (Gustman and Steinmeier, 2001) we found that those who overestimate the values of their pensions and Social Security in the years before retirement nevertheless do not eventually change their saving or retirement behavior by saving more over the next eight years, or retiring later. Nor do those who understate their plan values change their behavior. Accordingly, they must eventually adjust their consumption.

It is not that people are totally clueless about the incentives created by their retirement plans. An extensive retirement literature is characterized by a strong response 
of retirement to incentives from pensions and Social Security (e.g., Gustman and Steinmeier, 2005b). Moreover, changes in Social Security rules designed to encourage delayed retirement have clearly had predicted effects on retirement (Gustman and Steinmeier, 2009). One would certainly expect that it is easier for those with higher cognition to understand these complex rules. But we have been unable to find a direct

link empirically from cognition through measures of knowledge of pensions and Social Security to accumulated wealth.

We have tried a variety of specifications to ensure that the absence of a link between knowledge of pensions and Social Security and numeracy, and the knowledge variables and wealth, is not due to a particular specification we have adopted. We have tried specifications with and without pension wealth included as a covariate. If there is no link, we are left with a list of questions. Accepting the relation between numeracy and wealth, what exactly is the mechanism by which numeracy affects wealth? What calculations or behavior does numeracy affect that are not ultimately reflected in pension or Social Security knowledge?

\section{Policy Implications:}

Our findings raise questions about the avenues through which cognition and numeracy increase retirement wealth. Accordingly, our analysis raises questions about whether the apparently robust numeracy-wealth relation provides a basis for designing policies that are aimed at increasing retirement saving by increasing numeracy or financial literacy.

Financial education would seem to be a basic policy that would allow those with lower levels of numeracy to nevertheless save adequately for their retirement. The 
numeracy-wealth relation, which remains even after standardizing for the differences in earnings that result from higher numeracy, seems to suggest that those with higher numeracy have an easier time accumulating knowledge of financial instruments, understanding risk, and appreciating the need for, and the best ways to accumulate, retirement saving. But our findings suggest the numeracy-wealth relation may reflect something else. Perhaps numeracy reflects an unmeasured characteristic of the individual that cannot be learned but does generate higher wealth. If nothing else, these findings suggest a good deal of caution is warranted before assuming that classes in financial basics, tutorials or other efforts to convey financial knowledge will induce appropriate saving habits, choices in the face of risk, or a proper approach to spending down assets after retiring. Although these policy initiatives may well ultimately encourage additional saving, they should be carefully and rigorously evaluated on an individual basis before financial education and training programs are adopted on a significant scale. 


\section{References}

Banks, James and Zoe Oldfield. 2007. "Understanding Pensions: Cognitive Function, Numerical Ability and Retirement Saving”. Fiscal Studies 28(2):143-170.

Cagan, Phillip. 1965. The Effect of Pension Plans on Aggregate Savings.

New York: National Bureau of Economic Research.

Gerardi, Kristopher, Lorenz Goette and Stephan Meier. 2010. “Financial Literacy and Subprime Mortgage Delinquency: Evidence from a Survey Matched to Administrative Data”. Social Science Research Network.

Gustman, Alan L. and Thomas L. Steinmeier. 1993. "Pension Portability and Labor Mobility: Evidence from the Survey of Income and Program Participation". Journal of Public Economics 50: 299-323. 1999. "Effects of Pensions on Savings: Analysis with Data from the Health and Retirement Study". Carnegie-Rochester Conference Series on Puble Policy 50: 271-324. . 2001. "Imperfect Knowledge, Retirement and Saving”.

Michigan Retirement Research Center, Working Paper UM00-08. . 2005a. "Imperfect Knowledge of Social Security and

Pensions.” Industrial Relations 44(2): 373 -395. . 2005b. "The Social Security Early Retirement Age In A

Structural Model of Retirement and Wealth.” Journal of Public Economics 89( 2-3): 441463. . 2009. "How Changes in Social Security Affect Recent

Retirement Trends." Research on Aging. 31(2): 261-290.

Gustman, Alan L., Thomas L. Steinmeier and Nahid Tabatabai. 2010. Pensions in the Health and Retirement Study. Harvard University Press.

Katona, George. 1965. Private Pensions and Individual Savings. Ann Arbor:

Survey Research Center, Institute for Social Research, University of Michigan.

Lusardi, Annamaria and Olivia S. Mitchell. 2006. "Financial Literacy and Planning: Implications for Retirement Wellbeing,” MRRC Working Paper No. 2006-144. . 2007. "Baby Boomer Retirement Security: The Role of Planning,

Financial Literacy, and Housing Wealth,” Journal of Monetary Economics 54: 205-224.

McArdle, John J., James P. Smith and Robert Willis. 2009. "Cognition and Economic Outcomes in the Health and Retirement Survey”. NBER Working Paper 15266.

Ofstedal, Mary Beth, Gwenith G. Fisher and A. Regula Herzog. 2005.

"Documentation of Cognitive Functioning Measures in the Health and Retirement Study”. HRS Documentation Report DR-006. Institute for Social Research. Ann Arbor: University of Michigan.

Rohwedder, Susann and Kristin J. Kleinjans. 2006. "Dynamics of Individual Information about Social Security”. Rand.

Stango, Victor and Jonathan Zinman. 2009. "Exponential Growth Bias and Household Finance.” Journal of Finance 64(6): 2807-2849. 


\section{Appendix 1. Measures of Cognition, Demographic Characteristics, Income and Wealth}

\section{in Different HRS Subsamples}

Appendix Table 1 provides descriptive statistics for indicators of cognition, demographic characteristics, income, wealth and other variables used in our analyses. Column 1 shows the means and standard deviations for the full sample of couple households with at least one member aged 51 to 56 in 2004. The columns that follow restrict the sample to those with a pension, those with a matched employer pension plan description, those with a defined benefit plan, those with a defined contribution plan, and those expecting Social Security benefits at the early or normal retirement age.

As can be seen by selecting a row and comparing means across the columns of Appendix Table 1, there is not much variation in the independent variables as the sample is restricted to those with a pension, those with a pension who also have a matched employer plan, those with a DB plan, and those with a DC plan. To be sure, as seen in the first six rows of the table, cognition measures are slightly higher for those with pensions than for the general population of couple households. However, restricting the populations to those with a matched employer plan, those claiming a DB pension, or those with a DC pension, does not have a systematic effect on the cognition variables.

The means of some demographic measures do differ across populations. For example, because Hispanics have lower pension coverage than whites or blacks, they are a smaller share of the pension covered population than of the overall population. Income also varies with sample composition. Those with a pension have higher incomes than those without a pension, and those with a defined benefit (DB) pension have higher incomes than those whose pension is not DB. Also importantly, total wealth is higher 
among households with a pension, and total wealth is lower among those households with a DB pension. On the whole, the various sample restrictions have relatively modest effects on the means of listed variables. 
Appendix Table 1: Selected Measures of Cognition, Demographic Status, Income and Wealth, for Members of Two Person Households, Health and Retirement Study, Respondents Aged 51-56 in 2004 (Means and Standard Deviations in Various Subsamples)

\begin{tabular}{|c|c|c|c|c|c|c|c|}
\hline Independent Variables & $\begin{array}{c}\text { All Rs } \\
(51-56)\end{array}$ & $\begin{array}{l}\text { Rs with } \\
\text { Pension }\end{array}$ & $\begin{array}{l}\text { Rs with } \\
\text { Matched } \\
\text { Pension }\end{array}$ & $\begin{array}{l}\text { Rs with } \\
\text { Any DB }\end{array}$ & $\begin{array}{l}\text { Rs with } \\
\text { Any DC }\end{array}$ & $\begin{array}{c}\text { Rs Expecting } \\
\text { SS Benefits } \\
\text { At ER age }\end{array}$ & $\begin{array}{c}\text { Rs } \\
\text { Expecting } \\
\text { SS Benefits } \\
\text { At NR age }\end{array}$ \\
\hline \multicolumn{8}{|l|}{ Financial $\mathbf{R}$} \\
\hline TICS & $\begin{array}{c}5.37 \\
(1.68) *\end{array}$ & $\begin{array}{c}5.55 \\
(1.61)\end{array}$ & $\begin{array}{c}5.47 \\
(1.66)\end{array}$ & $\begin{array}{c}5.53 \\
(1.61)\end{array}$ & $\begin{array}{c}5.62 \\
(1.57)\end{array}$ & $\begin{array}{c}5.52 \\
(1.61)\end{array}$ & $\begin{array}{c}5.51 \\
(1.61)\end{array}$ \\
\hline Word Recall & $\begin{array}{c}5.46 \\
(1.46)\end{array}$ & $\begin{array}{c}5.66 \\
(1.35)\end{array}$ & $\begin{array}{c}5.74 \\
(1.34)\end{array}$ & $\begin{array}{c}5.69 \\
(1.33)\end{array}$ & $\begin{array}{c}5.70 \\
(1.34)\end{array}$ & $\begin{array}{c}5.57 \\
(1.42)\end{array}$ & $\begin{array}{c}5.56 \\
(1.42)\end{array}$ \\
\hline Numeracy & $\begin{array}{c}1.43 \\
(0.96)\end{array}$ & $\begin{array}{c}1.58 \\
(0.94)\end{array}$ & $\begin{array}{c}1.62 \\
(0.95)\end{array}$ & $\begin{array}{c}1.63 \\
(0.91)\end{array}$ & $\begin{array}{c}1.61 \\
(0.93)\end{array}$ & $\begin{array}{c}1.53 \\
(0.94)\end{array}$ & $\begin{array}{c}1.53 \\
(0.94)\end{array}$ \\
\hline \multicolumn{8}{|l|}{ Non-Financial $\mathbf{R}$} \\
\hline TICS & $\begin{array}{c}4.81 \\
(1.82)\end{array}$ & $\begin{array}{c}5.07 \\
(1.72)\end{array}$ & $\begin{array}{c}5.10 \\
(1.70)\end{array}$ & $\begin{array}{c}5.06 \\
(1.71)\end{array}$ & $\begin{array}{c}5.15 \\
(1.71)\end{array}$ & $\begin{array}{c}5.07 \\
(1.75)\end{array}$ & $\begin{array}{c}5.06 \\
(1.75)\end{array}$ \\
\hline Word Recall & $\begin{array}{c}5.40 \\
(1.45)\end{array}$ & $\begin{array}{c}5.57 \\
(1.34) \\
\end{array}$ & $\begin{array}{c}5.66 \\
(1.37) \\
\end{array}$ & $\begin{array}{c}5.61 \\
(1.40)\end{array}$ & $\begin{array}{c}5.61 \\
(1.38) \\
\end{array}$ & $\begin{array}{c}5.50 \\
(1.48) \\
\end{array}$ & $\begin{array}{c}5.50 \\
(1.48)\end{array}$ \\
\hline Numeracy & $\begin{array}{c}1.06 \\
(0.93)\end{array}$ & $\begin{array}{c}1.19 \\
(0.93)\end{array}$ & $\begin{array}{c}1.21 \\
(0.93)\end{array}$ & $\begin{array}{c}1.20 \\
(0.93)\end{array}$ & $\begin{array}{c}1.23 \\
(0.94)\end{array}$ & $\begin{array}{c}1.20 \\
(0.91)\end{array}$ & $\begin{array}{c}1.20 \\
(0.91)\end{array}$ \\
\hline \multicolumn{8}{|l|}{ All } \\
\hline Female & $\begin{array}{c}0.50 \\
(0.50)\end{array}$ & $\begin{array}{c}0.47 \\
(0.50)\end{array}$ & $\begin{array}{c}0.56 \\
(0.50)\end{array}$ & $\begin{array}{c}0.47 \\
(0.50)\end{array}$ & $\begin{array}{c}0.46 \\
(0.50)\end{array}$ & $\begin{array}{c}0.54 \\
(0.50)\end{array}$ & $\begin{array}{c}0.54 \\
(0.50)\end{array}$ \\
\hline Hispanic & $\begin{array}{c}0.14 \\
(0.35)\end{array}$ & $\begin{array}{c}0.09 \\
(0.28)\end{array}$ & $\begin{array}{c}0.09 \\
(0.29)\end{array}$ & $\begin{array}{c}0.08 \\
(0.28)\end{array}$ & $\begin{array}{c}0.08 \\
(0.27)\end{array}$ & $\begin{array}{c}0.12 \\
(0.33)\end{array}$ & $\begin{array}{c}0.12 \\
(0.32)\end{array}$ \\
\hline Non-white & $\begin{array}{c}0.15 \\
(0.36)\end{array}$ & $\begin{array}{c}0.15 \\
(0.36)\end{array}$ & $\begin{array}{c}0.15 \\
(0.36)\end{array}$ & $\begin{array}{c}0.17 \\
(0.37)\end{array}$ & $\begin{array}{c}0.14 \\
(0.35)\end{array}$ & $\begin{array}{c}0.14 \\
(0.35)\end{array}$ & $\begin{array}{c}0.14 \\
(0.35)\end{array}$ \\
\hline R's age & $\begin{array}{l}53.60 \\
(5.23)\end{array}$ & $\begin{array}{l}53.10 \\
(4.19)\end{array}$ & $\begin{array}{l}53.04 \\
(4.14)\end{array}$ & $\begin{array}{l}53.20 \\
(4.08)\end{array}$ & $\begin{array}{l}52.95 \\
(4.23)\end{array}$ & $\begin{array}{l}52.89 \\
(3.98)\end{array}$ & $\begin{array}{l}52.97 \\
(4.08)\end{array}$ \\
\hline Spouse's age & 53.60 & 53.35 & 53.66 & 53.37 & 53.14 & 53.54 & 53.54 \\
\hline
\end{tabular}




\begin{tabular}{|c|c|c|c|c|c|c|c|}
\hline Independent Variables & $\begin{array}{c}\text { All Rs } \\
(51-56)\end{array}$ & $\begin{array}{l}\text { Rs with } \\
\text { Pension }\end{array}$ & $\begin{array}{l}\text { Rs with } \\
\text { Matched } \\
\text { Pension } \\
\end{array}$ & $\begin{array}{l}\text { Rs with } \\
\text { Any DB }\end{array}$ & $\begin{array}{l}\text { Rs with } \\
\text { Any DC }\end{array}$ & $\begin{array}{c}\text { Rs Expecting } \\
\text { SS Benefits } \\
\text { At ER age }\end{array}$ & $\begin{array}{c}\text { Rs } \\
\text { Expecting } \\
\text { SS Benefits } \\
\text { At NR age } \\
\end{array}$ \\
\hline & $(5.23)$ & $(5.0)$ & $(4.78)$ & $(5.10)$ & $(5.05)$ & $(5.34)$ & $(5.32)$ \\
\hline R's \# of school years & $\begin{array}{l}13.20 \\
(3.10)\end{array}$ & $\begin{array}{l}14.11 \\
(2.39)\end{array}$ & $\begin{array}{l}14.57 \\
(2.32)\end{array}$ & $\begin{array}{l}14.30 \\
(2.37)\end{array}$ & $\begin{array}{l}14.13 \\
(2.36)\end{array}$ & $\begin{array}{l}13.54 \\
(2.79)\end{array}$ & $\begin{array}{l}13.54 \\
(2.79)\end{array}$ \\
\hline $\begin{array}{l}\text { R's spouse's \# of school } \\
\text { years }\end{array}$ & $\begin{array}{l}13.20 \\
(3.10)\end{array}$ & $\begin{array}{l}13.86 \\
(2.47)\end{array}$ & $\begin{array}{l}14.12 \\
(2.38)\end{array}$ & $\begin{array}{l}13.91 \\
(2.43)\end{array}$ & $\begin{array}{l}13.91 \\
(2.42)\end{array}$ & $\begin{array}{l}13.48 \\
(2.82)\end{array}$ & $\begin{array}{l}13.48 \\
(2.82)\end{array}$ \\
\hline HH total income** & $\begin{array}{c}103.2 \\
(134.6) \\
\end{array}$ & $\begin{array}{c}125.3 \\
(148.6) \\
\end{array}$ & $\begin{array}{l}124.9 \\
(133.7)\end{array}$ & $\begin{array}{c}132.1 \\
(169.1)\end{array}$ & $\begin{array}{c}122.0 \\
(118.6) \\
\end{array}$ & $\begin{array}{c}112.2 \\
(146.4)\end{array}$ & $\begin{array}{c}112.1 \\
(146.1)\end{array}$ \\
\hline $\begin{array}{l}\text { HH Wealth excluding } \\
\text { pension and SS wealth** }\end{array}$ & $\begin{array}{c}432.3 \\
(1,052)\end{array}$ & $\begin{array}{c}466.8 \\
(1,074)\end{array}$ & $\begin{array}{l}448.0 \\
(832)\end{array}$ & $\begin{array}{l}436.8 \\
(832)\end{array}$ & $\begin{array}{c}475.0 \\
(1,110)\end{array}$ & $\begin{array}{c}479.1 \\
(1,111)\end{array}$ & $\begin{array}{c}458.1 \\
(1,109)\end{array}$ \\
\hline $\begin{array}{l}\text { HH Wealth including } \\
\text { pension and SS wealth** }\end{array}$ & $\begin{array}{c}839.6 \\
(1,165)\end{array}$ & $\begin{array}{c}975.3 \\
(1,205)\end{array}$ & $\begin{array}{c}1002.7 \\
(982)\end{array}$ & $\begin{array}{l}1001.7 \\
(966)\end{array}$ & $\begin{array}{c}986.3 \\
(1,246)\end{array}$ & $\begin{array}{c}879.1 \\
(1,221)\end{array}$ & $\begin{array}{c}879.7 \\
(1,218)\end{array}$ \\
\hline $\mathrm{N}$ & 3418 & 1520 & 639 & 743 & 1078 & 2398 & 2415 \\
\hline
\end{tabular}

* Standard deviations are in parenthesis

* * In 1000 dollars 
Appendix Table 2 has three sections. Part A describes the underlying populations according to employment, pension and Social Security coverage, availability of matched pension plan descriptions from employers or Social Security records, and reported outcomes. Part B reports means of measures of knowledge of pensions. Part C does the same for measures of knowledge of Social Security. Given interest in the roles played in households by the spouse who is financially knowledgeable (as identified by the household), and important remaining differences between outcomes for men and women, the table separates the results both according to whether the household labels the respondent as the financially knowledgeable respondent (labeled as Financial R), or the other member of the household (Non-Financial R). The table also reports each of these outcomes by the sex of the respondent. Note also that in Appendix Table 2, the sample sizes differ as we move down the rows. These differences in sample composition should be borne in mind.

As can be seen in Appendix Table 2, Section A, row 3, 78 percent of men from couple households and 69 percent of women held a job in 2004. From row 5, 60 percent of employed men and 61 percent of employed women from couple households reported coverage by a pension. From row 7, 35 percent of men reporting a pension, and 50 percent of women, had a matched employer pension plan in 2004. About half of respondents with a pension on their current job report they have a defined benefit plan. Around 73 percent of men and 68 percent of women reported having a defined contribution (DC) plan. Because many individuals have both a defined benefit and a defined contribution pension, the total of the share of those with pensions holding a 
defined benefit plan, and the share of those with pensions holding a defined contribution plan, exceeds 1.0. Moving toward the bottom of Section A of the table, in couple households, 60 percent of men and 61 percent of women have a matched Social Security record. 
Appendix Table 2: Descriptive Data Regarding Pension Coverage and Pension Knowledge, Couple Households, Health and Retirement Study, Early Boomer Cohort, in 2004

\begin{tabular}{|c|c|c|c|c|c|c|c|c|c|}
\hline & \multicolumn{3}{|c|}{ All } & \multicolumn{3}{|c|}{ Financial R } & \multicolumn{3}{|c|}{ Non-Financial R } \\
\hline & All & Males & Females & All & Males & Females & All & Males & Females \\
\hline \multicolumn{10}{|c|}{ Part A: Indicators of Employment, Coverage, Plan Type, Matched Employer and Social Security Data } \\
\hline Total & 3418 & 1708 & 1710 & 1709 & 1041 & 668 & 1709 & 667 & 1042 \\
\hline Number Employed & 2510 & 1325 & 1185 & 1297 & 824 & 473 & 1213 & 501 & 712 \\
\hline \% Employed & 73 & 78 & 69 & 76 & 79 & 71 & 71 & 75 & 68 \\
\hline $\begin{array}{l}\text { Number Reporting Current } \\
\text { Pension }\end{array}$ & 1520 & 801 & 719 & 818 & 524 & 294 & 702 & 277 & 425 \\
\hline $\begin{array}{l}\text { Percent Reporting Current } \\
\text { Pension }\end{array}$ & 61 & 60 & 61 & 63 & 64 & 62 & 58 & 55 & 60 \\
\hline $\begin{array}{l}\text { Number Reporting Matched } \\
\text { Employer Pension }\end{array}$ & 639 & 280 & 359 & 340 & 197 & 143 & 299 & 83 & 216 \\
\hline $\begin{array}{l}\text { Percent Reporting Matched } \\
\text { Employer Pension }\end{array}$ & 42 & 35 & 50 & 42 & 38 & 49 & 43 & 30 & 51 \\
\hline $\begin{array}{l}\text { Percent (of R with current } \\
\text { pension) Reporting DB/comb }\end{array}$ & 49 & 50 & 48 & 52 & 52 & 51 & 46 & 45 & 46 \\
\hline $\begin{array}{l}\text { Percent (of R with current } \\
\text { pension) Reporting DC/comb }\end{array}$ & 71 & 73 & 68 & 73 & 75 & 70 & 68 & 70 & 67 \\
\hline $\begin{array}{l}\text { Number with Matched Social } \\
\text { Security Data }\end{array}$ & 2068 & 1029 & 1039 & 1068 & 664 & 404 & 1000 & 365 & 635 \\
\hline $\begin{array}{l}\text { Percent with Matched Social } \\
\text { Security Data }\end{array}$ & 61 & 60 & 61 & 62 & 64 & 60 & 59 & 55 & 61 \\
\hline $\begin{array}{l}\text { Number Expecting Social } \\
\text { Security benefit }\end{array}$ & 2647 & 1292 & 1355 & 1313 & 780 & 533 & 1334 & 512 & 822 \\
\hline $\begin{array}{l}\text { Percent Expecting Social } \\
\text { Security benefit }\end{array}$ & 77 & 76 & 79 & 77 & 75 & 80 & 78 & 77 & 79 \\
\hline \multicolumn{10}{|c|}{ Part B: Indicators of Pension Knowledge } \\
\hline $\begin{array}{l}\text { Percent (of R with current } \\
\text { pension) Reporting DK Plan } \\
\text { Type }\end{array}$ & 3 & 2 & 3 & 2 & 2 & 2 & 4 & 3 & 4 \\
\hline Number Firm and Respondent & 565 & 248 & 318 & 298 & 172 & 126 & 267 & 76 & 191 \\
\hline
\end{tabular}




\begin{tabular}{|c|c|c|c|c|c|c|c|c|c|}
\hline $\begin{array}{l}\text { Report of Plan Type Agree } \\
\text { ((broader restriction) }\end{array}$ & & & & & & & & & \\
\hline $\begin{array}{l}\text { Percent (of R with matched } \\
\text { pension) Firm and } \\
\text { Respondent Report of Plan } \\
\text { Type Agree (broader } \\
\text { restriction) }\end{array}$ & 90 & 89 & 89 & 88 & 87 & 88 & 89 & 92 & 88 \\
\hline $\begin{array}{l}\text { Number Firm and Respondent } \\
\text { Report of Plan Type Agree } \\
\text { (narrower restriction) }\end{array}$ & 170 & 68 & 102 & 79 & 47 & 32 & 91 & 21 & 70 \\
\hline $\begin{array}{l}\text { Percent (with matched } \\
\text { pension) Firm and } \\
\text { Respondent Report of Plan } \\
\text { Type Agree (narrower } \\
\text { restriction) }\end{array}$ & 27 & 24 & 28 & 23 & 24 & 22 & 30 & 25 & 32 \\
\hline $\begin{array}{l}\text { Percent (with matched } \\
\text { pension) Reporting DB only } \\
\text { with Matched DB only }\end{array}$ & 10 & 11 & 10 & 9 & 11 & 8 & 11 & 11 & 11 \\
\hline $\begin{array}{l}\text { Percent (with matched } \\
\text { pension) Reporting DC only } \\
\text { with Matched DC only }\end{array}$ & 16 & 16 & 16 & 15 & 15 & 15 & 17 & 18 & 17 \\
\hline $\begin{array}{l}\text { Percent with DB/comb } \\
\text { Reporting DK on Early } \\
\text { Retirement Age } \\
\end{array}$ & 9 & 7 & 12 & 7 & 7 & 7 & 12 & 9 & 15 \\
\hline $\begin{array}{l}\text { Percent with Matched } \\
\text { DB/comb Agreeing on Early } \\
\text { Retirement Age (On } \\
\text { Diagonal) }\end{array}$ & 41 & 45 & 37 & 40 & 46 & 32 & 41 & 43 & 41 \\
\hline $\begin{array}{l}\text { Percent with DB/comb } \\
\text { Reporting DK on Normal } \\
\text { Retirement Age }\end{array}$ & 7 & 5 & 10 & 5 & 4 & 7 & 9 & 5 & 11 \\
\hline $\begin{array}{l}\text { Percent with Matched } \\
\text { DB/Comb Agreeing on } \\
\text { Normal Retirement Age (On } \\
\text { Diagonal) }\end{array}$ & 34 & 37 & 32 & 36 & 41 & 28 & 33 & 28 & 35 \\
\hline Percent (of R with DB/comb) & 5 & 4 & 7 & 3 & 3 & 4 & 8 & 6 & 9 \\
\hline
\end{tabular}




\begin{tabular}{|c|c|c|c|c|c|c|c|c|c|}
\hline $\begin{array}{l}\text { with DB Reporting DK on } \\
\text { Expected Retirement Age }\end{array}$ & & & & & & & & & \\
\hline $\begin{array}{l}\text { Percent (of R with DB/comb) } \\
\text { Reporting DK on Normal } \\
\text { Retirement Benefits* }\end{array}$ & 42 & 34 & 52 & 38 & 30 & 52 & 48 & 42 & 51 \\
\hline $\begin{array}{l}\text { Percent with DB/Comb } \\
\text { Reporting DK on Expected } \\
\text { Retirement Benefits** }\end{array}$ & 40 & 31 & 51 & 37 & 28 & 52 & 45 & 37 & 50 \\
\hline $\begin{array}{l}\text { Percent with Matched DB } \\
\text { Agreeing on Benefits at } \\
\text { Expected Retirement Age (On } \\
\text { Diagonal) }\end{array}$ & 18 & 20 & 16 & 21 & 23 & 19 & 13 & 13 & 13 \\
\hline $\begin{array}{l}\text { Percent (of R with DC/comb) } \\
\text { Reporting DK on Early } \\
\text { Retirement Age }\end{array}$ & 13 & 10 & 18 & 10 & 7 & 16 & 18 & 15 & 20 \\
\hline $\begin{array}{l}\text { Percent (of R with DC/comb) } \\
\text { Answering DK on Account } \\
\text { Balance }\end{array}$ & 34 & 30 & 39 & 31 & 28 & 35 & 38 & 32 & 41 \\
\hline $\begin{array}{l}\text { Percent (of R with DC/comb) } \\
\text { Answering DK after Brackets } \\
\text { on Account Balance }\end{array}$ & 11 & 10 & 12 & 11 & 11 & 12 & 11 & 9 & 12 \\
\hline \multicolumn{10}{|c|}{ Part C: Indicators of Social Security Knowledge } \\
\hline $\begin{array}{l}\text { Percent (R expecting SS } \\
\text { benefits) Reporting DK on } \\
\text { Early Retirement Benefit }\end{array}$ & 37 & 28 & 45 & 32 & 26 & 42 & 42 & 32 & 48 \\
\hline $\begin{array}{l}\text { Percent (R expecting SS } \\
\text { benefits) Reporting DK on } \\
\text { Normal Retirement Benefit }\end{array}$ & 32 & 23 & 40 & 28 & 21 & 38 & 36 & 26 & 42 \\
\hline
\end{tabular}

*Includes only those who provided a normal retirement age

**Includes under dk those who could not provide an expected retirement age.

***Rs expecting benefits based on own work and/or spouse's work are included.

Source: Gustman, Steinmeier and Tabatabai (2010) 
Next we turn to the many measures of knowledge of pensions in Part B of Appendix Table 2. Together these measures confirm our findings from earlier work - the glass is half full, half empty. If we look at the fraction of the relevant populations who can call their plan type, ages of retirement or plan value, on average they do not do too badly. But if we look at measures of agreement between individual reports and relevant values obtained from employer plan descriptions, typically less than half fall on a diagonal indicating the respondent report and value obtained from the employer plan description agree. More specifically, plan values are reported in the following ranges, all in thousands of dollars: 20-40; 40-60; 60 to 80; 80-110; 110-150; 150 to 190; 190-240; 240-300; > 300. Plan values from respondents and firms are said to agree if both reports fall within the same range.

We begin with indicators of knowledge of plan type. A simple “don’t know” report is not a helpful place to start. As seen in Part B, row 1, only 3 percent of respondents report they do not know their plan type. As a result, it is unlikely that this measure is a very interesting dependent variable. Nor is it very helpful in explaining variation in wealth.

Other measures of pension knowledge are more interesting, however. If the measure of correctly identifying plan type is whether, when the firm reports a defined benefit plan, so does the respondent, as seen in row 3 of part B, agreement is obtained in roughly 90 percent of the cases. That is, according to this broad definition of a match, if either the worker or firm reports "both" (DB and DC) plan types, while the other reports only one plan type, we consider this to be a match. However, using a narrower definition of plan type, where a match requires that both the respondent and firm record indicate the 
plan is DB only, DC only, or both only, 24 percent of men and 28 percent of women in couple households agree with their employer report of plan type. Regarding the specifics, if the respondent reports a pension that is defined benefit or combination, the matched plan description is defined benefit or combination in 58 percent of the cases. The comparable match rate is 49 percent when the respondent reports the plan is DC or combo. In the case of reported plan type, there is little difference between financially knowledgeable respondents or those who are not labeled as financially knowledgeable respondents. However, note that each person is talking about their own pension, not their spouse's pension.

Age of eligibility for benefits is another key characteristic of pensions. Of those reporting a defined benefit or combination pension, 7 percent of males from couple households, and 12 percent of females from couple households, report they do not know at what age they will become eligible for early retirement benefits. Yet for those reporting a defined benefit pension whose employer agrees the plan is $\mathrm{DB}$, there is agreement between early retirement age reported by respondents and early retirement calculated from matched firm plan descriptions for 45 percent of males from couple households, and 37 percent of females. Turning to normal retirement ages, among those reporting coverage by a defined benefit pension, 5 percent of males from couple households and 10 percent of females report they do not know their normal retirement age. There is agreement on normal retirement age for those with a DB plan between the respondent report and the value computed from plan description for 37 percent of males from couple households and 32 percent of women. Among financially knowledgeable respondents, women (28 percent agreement with plan descriptions) know less than men 
(41 percent agreement) about the normal retirement age of their defined benefit pension. Among those who are not the financially knowledgeable respondent, women (35 percent agreement with plan description) know more than men (28 percent) about the normal retirement age from their defined benefit plans.

Skipping to the third row from last in Part B of Appendix Table 2, when those with defined contribution plans are asked about the age at which they will become eligible for early retirement benefits, 10 percent of men and 18 percent of women report they do not know.

Respondents exhibit similar limitations in their knowledge of benefit amounts as they did in their knowledge of age of retirement. Of those reporting they were covered by a defined benefit pension, 34 percent of men and 52 percent of women from couple households report they do not know the value of the benefits they will receive from their plan at normal retirement age. In a small minority of cases, the benefit at expected retirement age matches the benefit obtained from employer plan descriptions. The match rates are 20 percent for males from couple households, and 16 percent for females from couple households.

For males and females from couple households and females reporting coverage by a defined contribution pension, 30 percent of men and 39 percent of women answer they do not know what the balance is in their defined contribution pension. However, most of these are willing to report their account balance in the form of a bracket, which does not require them to report an exact amount. Among those reporting a DC plan, 10 percent of males from couple households, and 12 percent of females from couple households report 
they do not know their plan balances even after presented with ranges of account balances as an alternative to having to report exact amounts.

Having received a report from the Social Security Administration increases the information available to the respondent. Today, benefit reports are mailed annually to respondents. Nevertheless, some respondents still report they do not know what their Social Security benefits will be at early retirement age. More specifically, from Part C of Table 3, 28 percent of men from couple households, and 45 percent of women from couple households report not knowing their Social Security benefits at early retirement even when given the opportunity to provide an answer in the form of brackets. ${ }^{8}$

There are similar results concerning benefits at normal retirement age. For men and women from couple households, the percent reporting DK are 23 percent and 40 respectively.

\footnotetext{
${ }^{8}$ In examining knowledge of Social Security benefits, Rohwedder and Kleinjans (2006) consider the changes in knowledge over time. They find that HRS respondents do better in reporting Social Security wealth as they approach retirement. They conclude that respondents who retired when they planned do a good job of reporting Social Security wealth. However, a minority misreports their wealth, with 17 percent of their sample over or understating their future benefits by 20 percent or more.
} 


\section{Appendix 2: Variables Used in the Analysis}

\begin{tabular}{|c|c|}
\hline Variable name & Definition \\
\hline \multicolumn{2}{|l|}{ Knowledge Variables } \\
\hline DK- Plan type & R doesn't know plan type \\
\hline $\begin{array}{l}\mathrm{R} \text { and firm agree on all } \\
\text { plan types (broad } \\
\text { restriction) }\end{array}$ & $\begin{array}{l}\text { If self-rep=DB/comb\& firm-rep=DB/comb or } \\
\text { If self-rep =DC/comb \& firm-rep =DC/comb }\end{array}$ \\
\hline $\begin{array}{l}\text { Firm and } R \text { agree plan is } \\
\text { DB }\end{array}$ & Firm reports DB only, self-report DB only \\
\hline $\begin{array}{l}\text { Firm and } \mathrm{R} \text { agree plan is } \\
\text { DC }\end{array}$ & Firm reports DC only, self-report DC only \\
\hline $\begin{array}{l}\text { Firm reports DC \& self-rep } \\
\text { DB }\end{array}$ & Firm reports DC/comb, self-report DB/comb \\
\hline $\begin{array}{l}\text { Firm reports DB \& self-rep } \\
\text { DC }\end{array}$ & Firm reports DB/comb, self-report DC/comb \\
\hline DK-ER age for DB & $\begin{array}{l}\mathrm{R} \text { reports dk on the early retirement age for the most important } \\
\mathrm{DB} / \text { comb plan }\end{array}$ \\
\hline DK-NR age for DB & $\begin{array}{l}\mathrm{R} \text { reports dk on the normal retirement age for the most } \\
\text { important } \mathrm{DB} / \text { comb plan }\end{array}$ \\
\hline DK-ER age for DC & $\begin{array}{l}\text { R reports dk on the early retirement age for the most important } \\
\text { DC plan }\end{array}$ \\
\hline DK-DC balances & $\begin{array}{l}\mathrm{R} \text { reports dk on account balances for the most important DC } \\
\text { plan }\end{array}$ \\
\hline DK after brackets in DC & R reports DK after bracket questions for DC account balances \\
\hline R \& Firm agree on NR age & $\begin{array}{l}\text { Firm-rep of normal retirement age agrees with self-report within } \\
\text { ranges of } 2 \text { years for the most important DB/comb plan }\end{array}$ \\
\hline DK-XP benefits for DB & $\begin{array}{l}\mathrm{R} \text { reports dk on the benefits at expected age of retirement for } \\
\text { the most important } \mathrm{DB} / \text { comb plan }\end{array}$ \\
\hline $\begin{array}{l}\text { R \& Firm agree on } \\
\text { expected DB benefits }\end{array}$ & $\begin{array}{l}\text { Firm-rep of benefits at expected age of retirement agrees with } \\
\text { self-rep for the most important DB/comb plan }\end{array}$ \\
\hline DK-SS benefits at ER age & R reports dk on social security benefits at early retirement age \\
\hline DK-SS benefits at NR age & R reports dk on social security benefits at normal retirement age \\
\hline Current pension wealth & Sum of DB wealth and DC balances \\
\hline Current DB wealth & Self-rep expected DB benefits from current job \\
\hline Current DC wealth & DC balances from current job \\
\hline \multicolumn{2}{|l|}{ Cognition Variables } \\
\hline TICS & $\begin{array}{l}\text { Sum of series } 7 \text { and backward counting - Sum of correct } \\
\text { answers, average for the missing }\end{array}$ \\
\hline Word recall & $\begin{array}{l}\text { Average of immediate +delayed recall- Missing values replaced } \\
\text { with the average }\end{array}$ \\
\hline Numeracy & $\begin{array}{l}\text { Sum of dummies for } 10 \% \text { chance, winning lott, and interest on } \\
\text { savings calculations- Each dummy if correct }=1 \text {, else }=0\end{array}$ \\
\hline
\end{tabular}




\begin{tabular}{|l|l|}
\hline Variable name & Definition \\
\hline sTICS & Spouse's tics \\
\hline sWord recall & Spouse's Word recall \\
\hline sTotal numeracy & Spouse's total numeracy \\
\hline Ddel & Dummy var for delayed recall \\
\hline Dimm & Dummy var for immediate recall \\
\hline dbwc20 & Dummy var for backward counting \\
\hline dser7 & Dummy var for series 7 \\
\hline Mischnc & Dummy var for missing chance of getting disease \\
\hline Miswnn & Dummy for missing Winning lottery \\
\hline Misntrst & Dummy for missing interest on savings \\
\hline Other Covariates & \\
\hline Public & Dummy for if public employee \\
\hline Mispubl & Dummy for missing public employee variable \\
\hline Dunion & Dummy for union employee \\
\hline Misunion & Dummy for missing union employee \\
\hline Dontwrk & Dummy for not working Rs \\
\hline Rage & R's age \\
\hline Sage & Spouse's age \\
\hline Rage squar & R's age square \\
\hline Sage square & Spouse's age square \\
\hline Total income & Total household income -- used in wealth equations \\
\hline Total income square & Total household income square -- used in wealth equations \\
\hline Female & Dummy for gender \\
\hline Hispanic & Dummy var for hispanic \\
\hline Nonwhite & Dummy var for non-white \\
\hline Finr & Financial respondent \\
\hline Rschlyrs & R's number of years of education -- used in wealth equations \\
\hline Sschlyrs & $\begin{array}{l}\text { spouse's number of years of education -- used in both wealth \& } \\
\text { knowledge equations }\end{array}$ \\
\hline Dropout & If did not finish high school -- used in knowledge equations \\
\hline Somecol & R has some college education -- used in knowledge equations \\
\hline Colgrad & R has a college degree -- used in knowledge equations \\
\hline Postgrad & $\begin{array}{l}\text { R has more than a college degree -- used in knowledge } \\
\text { equations }\end{array}$ \\
\hline Snopen & Dummy for spouse with no pension \\
\hline Snomatchspd & Dummy for spouse with no matched spd \\
\hline sswca50 & SS wealth if claim now le 50k -- used in knowledge equations \\
\hline sswca100 & $\begin{array}{l}\text { SS wealth if claim now <= 100k }>50 \mathrm{k} \text {-- used in knowledge } \\
\text { equations }\end{array}$ \\
\hline sswca150 & $\begin{array}{l}\text { SS wealth if claim now <= 150k > 100k -- used in knowledge } \\
\text { equations }\end{array}$ \\
\hline sswca200 & SS wealth if claim now <= 200k > 1500k -- used in knowledge \\
\hline
\end{tabular}




\begin{tabular}{|l|l|}
\hline Variable name & Definition \\
\hline \hline & equations \\
\hline sswca201 & SS wealth if claim now > 200k -- used in knowledge equations \\
\hline dmsswca & $\begin{array}{l}\text { Dummy var for missing ss wealth at claim now age -- used in } \\
\text { knowledge equations }\end{array}$ \\
\hline
\end{tabular}

